\title{
Causas y consecuencias de la Pandemia COVID-19. De la inmovilidad de la humanidad a la circulación desconcentrada de personas ${ }^{1}$
}

Causes and consequences of the Covid-19 Pandemic. From the immobility of humanity to the deconcentrated circulation of people

Dino Di Nella ${ }^{2}$

Universidad Nacional de Río Negro - Argentina

Victoria Ibáñez

Universidad Nacional del Comahue - Argentina

Revista Derechos en Acción ISSN 2525-1678/ e-ISSN 2525-1686

Año 5/No 15, Otoño 2020 (21 marzo a 21 junio), 415-485

DOl: https://doi.org/10.24215/25251678e407

\section{Introducción}

Cuando comenzamos a reflexionar sobre los aspectos sociales y jurídicos vinculados a la COVID-19, poca cosa circulaba aún por las revistas científicas y sociales. Evidentemente estaba en proceso de elaboración, porque un par de semanas después,

\footnotetext{
1 Este trabajo se realiza en el marco del Proyecto PI-UNRN-40-C-803, de la Sede Atlántica de la Universidad Nacional de Río Negro.

2 Abogado (UNLP), Sub Director del Centro de Investigación en Derecho Crítico de la UNLP. Profesor Ordinario Efectivo Adjunto Categoría II (Programa Incentivos a la Investigación) Grupo Internacional Copolis-Adalquí Sede Atlántica - Universidad Nacional de Río Negro Oficina 5, AV. Don Bosco y Leloir. Viedma (08500). Río Negro. Argentina.

3 Abogada (UNLP), integrante del Centro de Investigación en Derecho Crítico de la UNLP y del Colectivo de Acción Jurídica, Social y Cultural Adalquí.
} 
pronunciarse sobre la actualidad fue como una obligación que tendrían los y las intelectuales (que pretendan jactarse de ser tales). Principalmente, cabía hacerlo respecto al devenir futuro, ante una eventual bisagra, un antes y un después de la COVID-19, que devendría proféticamente en irreductibles e inevitables transformaciones sociales. Una especie de ATR intelectual de la ley y el nuevo orden.

Sin embargo, parece que las reflexiones y eventuales conclusiones se basan en una empírea aun escasa y provisional, o en ausencia de toda evidencia; puros indicios construidos sobre conjeturas y verosímiles de diversa índole y calado. Sobre la base de un escaso saber sobre el SARS-Cov-19, tenemos la certeza de que las estadísticas están insalvablemente viciadas, incluyendo en aspectos tan elementales como el número exacto de personas infectadas (debido a la falta de pruebas de laboratorio) o de fallecidas (debido a la sub-notificación de casos). $\mathrm{E}$ incluso, si desde un mero acto de fe quisiéramos creer, los números no nos dicen nada sobre los determinantes sociales de las personas damnificadas (Sousa Santos, 2020).

La principal dinámica que observamos tiende más a la radicalidad, exacerbación o simple desarrollo desinhibido de los trazos característicos de las sociedades y estados pre-pandémicos, que a su transformación novedosa. En todo caso, la pandemia ha operado como un acelerador de procesos latentes o en marcha.

Se suele escuchar a un político decir que nunca hace zanjas tan grandes que después no las pueda saltar... porque todo es muy dinámico y siempre hay que mantener la posibilidad del diálogo con quien sea. No es la pretensión de estos párrafos construir abismos inconmensurables; apenas esmerilar los extremos mas filosos de la realidad social y jurídica a la que nos han llevado con la pandemia.

La pandemia y la cuarentena suelen abordarse de manera indiferenciada, pero conviene no hacerlo de ese modo. Por un lado, hay que distinguir los discursos, las prácticas y las medidas socio sanitarias destinadas al abordaje de la enfermedad 
COVID-19. Y por otro lado, deben observarse las medidas destinadas a la reducción del riesgo de transmisión comunitaria del Coronavirus SARS-CoV-2. La enfermedad, tanto su prevención como su tratamiento y eventual cura, tienen diversos tipos de respuestas. Y la prevención y elusión de la circulación del virus por su transmisión comunitaria en aglomeraciones de personas concentradas en un espacio físico cerrado, tiene otro tipo de respuestas. Dentro de estas últimas, la inmovilización humana por encierro en un lugar de confinamiento determinado es solo una de las múltiples medidas posibles, que presupone evidentemente, la priorización de unas necesidades sobre otras. Poder pensar críticamente sobre estos aspectos, es fundamental para concebir todas las alternativas que seamos capaces de elaborar.

Desde ya, conviene dejar en claro nuestra total adhesión a que los estados tengan un rol activo en la prevención y elusión de la circulación del virus, sin ningún tipo de subordinación al economicismo que todo lo subordina a la producción de plusvalía. Aun así, hay cierta tendencia a tratar a los que discrepan de la línea del santo confinamiento, como simples idiotas infectados de mentalidades fétidas proto-fascistas de un barrio cheto de cualquier país cool, o con un odio irracional a la ciencia (ciencicracia del tecno-academicismo de la élite global), o devotos adherentes a un anticuado fundamentalismo religioso (de los seguidores más irracionales de Trump) (Harrington, 2020). Vernáculamente, por supuesto, no cabe otra que el mote de trosko/a que le hace el juego a la derecha, aunque la derecha nunca nos haya interpelado ni marcado ninguna agenda.

Este texto se efectúa sin más pretensiones y recursos que la capacidad persuasiva devenida de la argumentación expuesta, y la convicción de que todo ejercicio del poder estatal no debe ser ilimitado. Uno de los límites de ese ejercicio del poder es su crítica. Asumimos que la valoración de los textos académicos sobre temas abiertos, no zanjados, de actualidad, y en especial, cuando tratan de procesos sociales de la masividad que conlleva una pandemia, se efectúa en condiciones asimétricas de poder. Los errores, dificultades, fracasos, perjuicios y daños son 
socializados, repercutiendo en las agencias con menos poder; y los aciertos, logros, beneficios y frutos suelen ser aprehendidos por quienes han tenido mayor prestigio o visualización. Se diga lo que se diga, la superación de la Pandemia propenderá hacia el fortalecimiento de las posiciones relativas de los oficialismos (políticos, económicos, intelectuales, académicos...) en todo el mundo. Ante las crisis y su superación, se prefiere reforzar los aspectos más positivos y esperanzadores, como la cantidad de gente que se ha salvado (mas que la cantidad de personas que han muerto o que se podrían haber evitado). En ese discurso exitista de salida amable de la gran debacle, quienes señalen las partes ocultas, las debilidades de las estrategias en marcha o las consecuencias dañinas de las decisiones adoptadas, será extirpado como simple chivo expiatorio (temerario, ignorante, acientífico). Bien; acostumbrades ya, asumimos el riesgo. Haremos en este trabajo un abordaje sociojurídico de indagación crítica - a partir del marco y contexto en que se desarrolla- de la medida de inmovilización humana residencial generalizada como medida de anticipación a la transmisión comunitaria del virus SARS-Cov-19 y las posibilidades de adoptar otras menos gravosas a la integralidad de los derechos humanos. Porque ninguna pandemia que conlleve una emergencia sanitaria crítica, un desastre o una catástrofe, puede transformarse en un estado de excepción. Y porque como se verá en los siguientes párrafos, salvar vidas y asumir el resto de las consecuencias de las pandemias ya desatadas, también puede hacerse democratizando los espacios públicos y comunitarios necesarios para reducir sus daños y erradicar las causas que las generan.

\section{Las causas de las Pandemias}

Abordar el surgimiento de las enfermedades zoonóticas - aquellas transferidas de animales a humanos- implica atender su principal causa, es decir, el impacto de las actividades humanas en los ecosistemas. Esto significa reconocer las estrechas relaciones entre la salud humana, animal y ambiental. En 
las últimas décadas, las enfermedades zoonóticas representan el $75 \%$ de todas las enfermedades infecciosas emergentes en humanos (Programa de las Naciones Unidas para el Medio Ambiente, PNUMA, 2016). El ébola, la gripe aviar, la gripe por el virus H1N1, el síndrome respiratorio del Medio Oriente (MERS), la fiebre del Valle del Rift, el síndrome respiratorio agudo severo (SARS), el virus del Nilo Occidental, el virus del Zika y el nuevo COVID-19 son solo algunas de las que han causado pandemias o han amenazado con causarlas; dejando claro que la del SARSCov-19 no será la última.

Más allá de los aspectos microbiológicos y específicamente virológicos, las principales actividades humanas que han influido en la generación de pandemias y repercutido en la salud de millones de personas, son la destrucción de ecosistemas naturales, el tráfico de fauna, la extinción de especies silvestres, el cambio climático planetario y el proceso de urbanización global (Mastrangelo y Ruiz, 2020).

Estas actividades humanas no son simple desidia de algunos ni se han producido por generación espontánea, aleatoria o azarosa; sino que derivan directamente del modelo de explotación económica extractivista-productivista - principalmente el agro-negocio, la mega-minería y la explotación petrolera- en su actual fase del tardo-colonialismo financiero, que a su vez, responde al paradigma consumista, exitista e individualista productor del homo-economicus actual (Zaffaroni, 2020).

Así, al cambiar el uso del suelo para los asentamientos, la agricultura, la tala o las industrias y sus infraestructuras asociadas se han producido alteraciones importantes en estos ecosistemas, eliminando las fronteras o diferenciaciones de los hábitats naturales que normalmente separan a los humanos de la vida silvestre. Más aún, se han facilitado los puentes para que los patógenos pasen de los animales a las personas, por ejemplo, al reducir la biodiversidad que ayuda a regular las enfermedades —cuanto más biodiverso es un ecosistema, más difícil es que un patógeno se propague rápidamente- 
La situación se agrava con la crisis climática provocada por el aumento sin precedentes de las emisiones de gases de efecto invernadero en nuestra atmósfera. Los cambios en la temperatura, la humedad y la estacionalidad afectan directamente la supervivencia de los microbios en el medio ambiente y la evidencia sugiere que las epidemias serán más frecuentes a medida que el clima siga transformándose.

Por ello, el conflicto entre economía y vida solo puede ser negado por quienes no quieren escuchar. Evitar muertes es un tema económico, sin mas. Joan Queralt afirma en este sentido que en todo caso la pregunta que cabe es ¿Cuántos muertos vale un punto del PBI? (Queralt, 2020) Y desde allí, ¿Si los que mueren son 10.000 personas, se justifica parar de producir y perder un punto del PBI? ¿Cuándo la curva baje y sean 30 las personas fallecidas en un determinado período, ya se cambia de fase y se reactiva la producción de mercancías?. ¿Y si se muere una sola persona, se puede asumir eso como un efecto colateral de un determinado sistema productivo y sanitario, y ya está?

Por lo menos en este contexto actual, pareciera que "no está". Claramente parece consolidarse cierta deslegitimación de los sectores capitalistas neoliberales - principalmente en ciertas áreas como en las políticas sanitarias-. Aparecen discursos que reclaman subordinar, al menos parcialmente, a algunos sectores de la economía, a las reglas de un Estado que permita establecer un nuevo ethos centrado en lo público y en la satisfacción de ciertos derechos básicos de toda la humanidad. Recordemos igualmente que dicha deslegitimación no es dialéctica ni estrictamente confrontativa. Solo cuestiona la hegemonía de la producción de renta por sí mismas; en ese marco, desde una economía social realista, nunca "salvar una vida humana" puede ser una idea antieconómica.

Ahora bien, esta deslegitimación del neoliberalismo - que pareciera afectar solo a la producción de renta financiera especulativa- no es óbice para que el sistema conserve todo su poder fáctico, toda su capacidad de incidencia, para forzar decisiones que le resulten favorables a sus intereses. Por lo tanto, 
es una deslegitimación política —o del ámbito de su filosofía política- pero en ningún caso, implica su derrota.

De cualquier forma, el deterioro progresivo en la vida y la salud de las comunidades y la reducción de la capacidad de la respuesta inmunológica humana ante las diferentes agresiones a la que ha llevado este sistema de producción, consumo y maximización de la renta financiera; es incuestionable. Para el Instituto de Salud Socioambiental,

“...Los modos de producción explotan nuestros territorios, con la consecuente contaminación del agua, aire y suelo con agrotóxicos, microplásticos, metales pesados y gases tóxicos, imponen la deforestación con corrimiento de la frontera agrícola, la explotación animal en condiciones deplorables, constituyen un medio de cultivo ideal para la génesis de mutaciones virales (...) Si no nos reconocemos como parte de un todo viviente, dinámico y naturalmente cíclico, será complejo salir fortalecidas de esta crisis..." Instituto de Salud Socioambiental, 2020).

En el mismo sentido, Inger Andersen, directora ejecutiva del PNUMA, manifestaba que “... Estamos íntimamente interconectados con la naturaleza, nos guste o no. Si no cuidamos la naturaleza, no podemos cuidar de nosotros mismos..." (Andersen, 2020)

Las tecnologías que organizan ese gobierno de la vida han sido fundamentales para el despliegue del capitalismo. Para Foucault (1974), el gobierno de la vida constituye un ámbito autónomo de actuación y regulación de la vida misma, sus formas y límites, sus amenazas y defensas. La población se constituirá como una categoría que estará en la encrucijada de todo un conjunto de saberes y tecnologías de gobierno a través de la medicina, la sociología, la biología, la psicología, la psiquiatría y, cómo no, la estadística como aproximación transversal a todas ellas.

La escala biopolítica permite, en efecto, conocer y gobernar fenómenos considerados hasta entonces como accidentales o azarosos, a partir de poder determinar su frecuencia, incidencia o patrones de repetición a lo largo del tiempo. Se desplegarán así todo un conjunto de mecanismos destinados a gestionar la 
seguridad, detectar situaciones de riesgo o "peligrosidad", que permitan determinar el modo de intervención política necesaria. Peligrosidad en términos de enfermedad, a través de la higiene pública, el control y gestión de las enfermedades, prevención de las epidemias, políticas de salud tanto en casas y lugares de trabajo como en barrios y ciudades. Peligrosidad también en términos de criminalidad, necesidad de determinar qué riesgos de criminalidad son inherentes a determinados sujetos, lugares o situaciones, el control y vigilancia generalizados de la población como métodos que permitan intervenir en caso necesario.

El mismo Foucault sostiene que el ser humano constituye una materia prima, como la tierra o los recursos naturales, que los agentes con poder se esfuerzan en potenciar para extraer todos los beneficios posibles. Ugarte nos lo presenta así:

“...La imagen de un Estado-guardabosques que espera al momento adecuado para hacerse con la mejor madera es sustituida por la de un Estado-jardinero que todos los días vigila las plantas y abona, poda, injerta, elimina las malas hierbas, riega y cosecha cada fruto en el tiempo adecuado; momento éste que varía de una planta a otra: pensemos en la capacidad que tienen las vacunas para proteger a los individuos, el empeño en reducir las muertes por accidentes de tráfico a través de medidas como el carné por puntos, el esfuerzo por aumentar la movilidad de los afectados por una enfermedad grave a través de la inversión de enormes recursos en investigación..." (Ugarte Pérez, 2005).

La biopolítica va, pues, de la mano de la instauración de la norma como un mecanismo de orden y organización social cuya centralidad pone en crisis el orden social que pivotaba en torno a la ley. En efecto, si la ley era concebida como un mecanismo que prohíbe, impidiendo y limitando determinadas acciones, la norma actuará positivamente prescribiendo o regulando qué es lo que debe suceder, y cómo. Eso no significa que la ley desaparezca o retroceda en favor de la norma, pero sí quedará resituada a partir de ese nuevo paradigma de gobierno. 
Así, mucho más allá del androcentrismo, el concepto de vida se amplía en todas sus dimensiones sociales y culturales, poniendo en superioridad a la vida humana.

\section{El rol de los Estados y la hegemonía del poder}

El proceso ecoambiental descripto es fruto de un proceso en el que cinco mil pueblos son gobernados en el marco de casi 200 Estados que regentean un sistema económico global de una concentrada hegemonía de los capitales de especulación financiera internacional con la maximización de la renta como única meta (Di Nella e Ibáñez, 2020). Estos Estados son básicamente gobernados por élites de algunos pueblos, con la consecuente subordinación del resto. Para poder ejercer esa dominación -y buscando la legitimación de ese poder estatal- se instrumentan dispositivos de homogeneización de las diversidades en todas sus facetas.

Así, construirán una única identidad nacional, una única ley para un mismo territorio, una única soberanía - delegada en la soberanía estatal-, una única voz en la interpretación de las voluntades y deseos populares. Con ello se intentará configurar sujetos que respondan a una inclusión meritocrática, vinculándola a su capacidad de consumo. El sistema de la maximización de la renta mercantil y su capacidad de acumulación financiera, sumado a ese perfil meritocrático y exitista, será el "gran ethos" ordenador de la sociedad capitalista, patriarcal y adultocéntrica. Esta gran maquinaria de control y subordinación del conjunto de las disidencias a ese modelo hegemónico - paradojalmente el $87 \%$ de la población mundial- produce y reproduce una gran fábrica de desigualdad social (Di Nella 2006).

Sin embargo, lejos de permanecer impasibles, los diferentes grupos generarán - en el marco de diversos movimientos sociales- procesos de permanente contraste y conflicto con el "sujeto de mercado". Claro ejemplo de ello, serán los movimientos feministas en su disrupción con la hegemonía patriarcal y androcéntrica, las resistencias vinculadas a los movimientos 
ecologistas y las luchas de los pueblos naciones del mundo en sus reivindicaciones etno-nacionales.

También podemos mencionar los movimientos que plantean una nueva arqueología no adultocéntrica y desvinculada de la idea tradicional de las niñas, niños y adolescentes como simples personas de futuro; se trata de una concepción de sujetos en una etapa más de la vida, que merece ser vivida como cualquier otra.

Del mismo modo, surgen reivindicaciones de personas que producen algún tipo de plusvalía en un nuevo ethos, que no es simplemente el de trabajadoras/es para la producción de mercancías y la renta empresaria. Por el contrario, se vinculan a la economía de los cuidados para la vida humana; convergentes también con los modelos ecofeministas de existencia (Di Nella, Giordana y otras, 2019).

Esto se suma a una convulsión planetaria más generalizada, en dónde — solo en 2019- se han producido grandes revueltas en lugares tan disímiles como Hong Kong, Líbano, Francia, Catalunya, Puerto Rico, Colombia, Perú, Ecuador, Haití, Uruguay, Venezuela, Bolivia y Chile (Fiore, 2019). Todas ellas tienen en común un gran descontento de la población con medidas estatales puntuales pero sintomáticas del tardo-colonialismo financiero (Zaffaroni, 2020), que superaron el reclamo inicial de renuncia de los mandatarios que las habían ordenado, para convertirse en movimientos más profundos con reclamos económicos, políticos o sociales radicalmente transformadores.

Ante esto, lo que hay es un Estado en permanente disputa entre esas fuerzas sociales y comunitarias y las élites de los sectores económicos concentrados. En esa constante confrontación, algunas de las reivindicaciones se consagran en derechos humanos que en muchos casos funcionan como meras compensaciones de las exclusiones, marginalidades y externalidades que genera este modelo de producción y consumo y la subordinación del Estado a él. Sin embargo, este reconocimiento de las reivindicaciones sociales como derechos humanos no fueron ni son simples concesiones de los sectores dominantes. 
Cada coma, cada letra, cada palabra de esa consagración de derechos son el producto de la puja en esa correlación de fuerzas popular-comunitarias y económico-financieras. Para Dussel (2006: p.142),

"...Los nuevos derechos no se "sacan" de la lista de los derechos naturales, emergen por el contrario de las luchas populares. Los nuevos movimientos sociales toman conciencia, a partir de su corporalidad viviente y doliente, de ser víctimas excluidas del sistema de derecho en aquel aspecto que define sustantivamente su praxis crítica liberadora. (...) Esta negatividad es vivida como una "falta-de derecho a" un derecho vivido como necesario por la intersubjetividad pero inexistente positivamente. Es decir, los nuevos derechos se imponen a posteriori, por la lucha de los movimientos, que descubren la "faltade" como "nuevo-derecho"...".

Es probable que durante los próximos años nos encontremos cada vez más, con nuevos-viejos discursos y dispositivos que actualizan históricamente las disputas entre el bomo económicus (como constructo del proyecto del tardo-colonialismo financiero) y el bomo comunitas (como proyecto eco-sociofeminista). Indefectiblemente, ello conlleva abordar las causas de los procesos socioambientales que padecemos y no solo la gestión de sus consecuencias.

En torno a ello, será relevante observar la enorme brecha abierta entre las declaraciones formales de los derechos colectivos, económicos, socioambientales y culturales; y su vigencia sociológica. Más aún, será necesario observarlo desde una perspectiva sociojurídica crítica que nos permita tensionar la real trascendencia del derecho en las relaciones humanas como imperativos o construcciones de consensos y acuerdos. Todos ellos deberán hallarse a partir del respeto de los disensos y las discordancias.

En la pre-pandemia el Estado, inicial y predominantemente al servicio del capital, estaba respondiendo a los movimientos sociales y sus reivindicaciones de vigencia sociológica de 
diversos derechos humanos, con políticas de control y subordinación violenta. Pero el propio Estado estaba siendo desbordado e interpelado en su legitimidad, desde la lógica del estado de derechos y la pluralidad de construcciones diferenciadas de los pueblos naciones del mundo, reflejando las contradicciones de la sociedad.

Acá estábamos en el escenario pre-pandemia, desarrollando en ese contexto gran parte de nuestra existencia, cuando irrumpió la COVID-19: la pandemia, el virus, la enfermedad y la muerte. Sin embargo, no es una irrupción inédita. Comparando con otras grandes causas de muerte masiva, podemos comprobar que la peste negra (año 1348) mató 30 millones de personas en dos años; en la epidemia del cólera (1900) murieron un millón de personas; la Primera Guerra Mundial (1914) terminó con un saldo de 15 millones de muertos en 4 años; y la Segunda Guerra Mundial (1945) provocó 60 millones de muertos en 6 años. Pero la gripe de Kansas (conocida sin embargo como Gripe Española, 1918) fue la peor epidemia humana de la historia. Hasta hace pocos años no existía conciencia pública ni información accesible sobre su verdadera magnitud. Fue la causa del mayor número de muertos en el menor tiempo en la historia de la humanidad, ya que en menos de ocho meses murieron entre 30 y 100 millones de personas (Müller, 2010).

Es muy factible que superada la etapa mas crítica o traumática de la COVID-19, las personas rápidamente se comporten con cierta indiferencia, incluso como si no hubiese existido o se tratase de un episodio lejano que nada tiene que ver con la vida cotidiana. Tras una tragedia masiva el silencio y/o la evasión suele ser una estrategia para poder seguir una vida —en apariencia- normal. Sin embargo, la memoria viva de la sociedad hace imposible borrar las huellas de tal fenómeno, volviendo una y otra vez en forma de memoria oral, literatura o arte.

Quien no puede callar es el Estado. Desde el advenimiento de la pandemia por la COVID-19, uno de los emergentes sociales es la legitimación de lo estatal para regular estas cuestiones con amplias restricciones de derechos colectivos e individuales 
homogéneos. Además, la gestión estatal de la pandemia se ha caracterizado por la centralización y concentración del poder público en todos sus niveles, desde las comunidades hacia los diferentes niveles del Estado. Y dentro del Estado, la centralización y concentración se produce desde los gobiernos municipales y provinciales hacia el gobierno central y hacia los poderes $\mathrm{u}$ órganos ejecutivos unipersonales, concentrando en una o dos carteras ministeriales la gran mayoría de las decisiones.

Todo ello se produce en el contexto de un estado federal - aunque no lo parezca, Argentina lo es-. Las presidencias no tienen excelentes gobernadores/as; son las/los gobernadoras/es quienes implementan medidas a través del/la presidenta/e, del congreso o de la administración de justicia federal que tienen. Las personas pueden ser buenas o malas gobernando y lo serán indistintamente en el gobierno federal como en los estados federados. El problema tiene que ver con la baja incidencia de las comunidades en esos gobiernos. Máxime en un país con semejante enormidad territorial, dónde se impone la necesidad de contar con gobiernos próximos a sus pueblos y a sus necesidades.

Por otro lado, los mecanismos legislativos deben funcionar como una de las formas de ejercicio del poder público en cualquier período. Sin embargo, el gobierno federal se ha asimilado al Poder Ejecutivo. La existencia del recurso instaurado por el pacto de olivos del menemato-alfonsinista en 1994 - por el cual es constitucional sanear legalmente 20 decretos de necesidad y urgencia en períodos ordinarios de sesión legislativa de una sola cámara - no reemplaza la necesidad de un mayor republicanismo y democratización de dicho poder público a través de decisiones más colegiadas y participativas en las respuestas a la pandemia.

Esta participación por parte del Congreso, subordinada a las decisiones ejecutivas en tiempo y forma, también ha sucedido con todo el sistema de la Administración de Justicia. El Poder Judicial ha quedado absolutamente relegado en esta dinámica, como si su servicio público y esencialidad tratara de simples 
beneficios o cuestiones menores respecto de la vida cotidiana de las personas. Para que se establezcan las garantías jurídicas frente a las personas físicas o jurídicas obligadas son imprescindibles sus intervenciones en períodos de restricción de derechos. Máxime cuando se fundamentan en una prevención genérica, difusa, potencial y objetiva; éstas nada tienen que ver ni con la conducta, ni con las circunstancias de la persona a la que se le restringen sus derechos humanos básicos. Por el contrario, es cuando más deben diseñarse mecanismos de acceso a la justicia ágiles que permitan respuestas inmediatas a medidas de carácter absolutamente excepcional como las adoptadas por el Poder Ejecutivo Nacional. Recordemos, muchas de las decisiones gubernamentales que están instrumentando — según sus mentores- el confinamiento domiciliario en núcleos de convivencia familiar uniresidencial, se hacen a través de resoluciones administrativas de menor jerarquía.

Hasta el momento son pocos los casos que han llegado a instancias judiciales, aunque paradójicamente todos afectan derechos colectivos y muchos derechos esencialísimos de los grupos más vulnerabilizados. Un ejemplo lo constituyen los derechos de niños, niñas y adolescentes, en relación a la continuidad de sus vínculos dentro de los regímenes de comunicación con sus progenitores no convivientes que hasta hace no mucho estaban prohibidos (vg., fallo Juzgado Civil 4 V., E. P. c/ F.P., D. s/Divorcio, Buenos Aires, mayo de 2020). Cabe entonces determinar cuáles son esos servicios legislativos y judiciales esenciales que no pueden cesar durante una pandemia, y brindarlos.

En conjunto se observa el consolidado dirigismo personalista del proceso de respuesta a la pandemia, que acabó subordinando las dinámicas y procesos sociales de protesta pre-pandemia - e incluso a gran parte de las confrontaciones políticas partidarias - a los designios de un puñado de cargos gubernamentales unipersonales de los Estados. Ello no ha redundado, claro está, en que los gobiernos aborden de manera prioritaria y urgente las causas y factores estructurales que 
originan las protestas globales, ni el surgimiento de los virus. Por tanto, no tendremos mas remedio que abocarnos a gestionar las consecuencias de las pandemias.

\section{Gestionar las consecuencias de la Pandemia}

En el abordaje de las consecuencias de las pandemias viene prevaleciendo la homogeneización poblacional, esencialmente sobre la base bio-médica de los factores de riesgo de transmisión comunitaria del Coronavirus SARS-CoV-2 causante de la enfermedad denominada — desde febrero de 2020 - COVID-19.

Esta distinción resultará relevante en sus perspectivas clínicas y virológicas. La perspectiva clínica se refiere a cuando una persona tiene síntomas de la enfermedad; es tratada - ante la ausencia de vacunas- manteniendo en funcionamiento y/o reforzando y ayudando con paliativos al sistema inmunológico del cuerpo humano hasta que pueda combatir el virus, y su cura clínica, consiste en la ausencia de esos síntomas. La perspectiva virológica comprueba mediante pruebas de laboratorio (test, hisopados $\mathrm{u}$ otros medios) que hay presencia del virus en el cuerpo humano, y su cura consiste en la ausencia del virus dentro de ese organismo. Por tanto, personas clínicamente curadas pueden seguir bastante tiempo más con el virus en su cuerpo y consecuentemente, contagiando a otras personas.

En este trabajo nos abocaremos principalmente a la transmisión comunitaria del Coronavirus SARS-CoV-2. En este sentido, el virus se ubica en las gotículas de las secreciones (mucosa, saliva...) que están o salen despedidas de la nariz, la boca o los ojos de una persona infectada (están también en la sangre, pero no es frecuente estar en contacto con la sangre de otras personas). En general, estas gotículas permanecen dentro del cuerpo humano y cuando salen son relativamente pesadas, no llegan muy lejos y caen rápidamente al suelo o a los objetos que estén debajo de la boca o la nariz.

El Coronavirus SARS-CoV-2 "sobrevive y se reproduce", básicamente, dentro de un cuerpo humano o animal vivo y durante 
un período reducido de tiempo - aun no determinado pero que durará varias semanas-. Tras ese tiempo la propia acción del organismo lo extingue o expulsa. Si no es incorporado dentro de otro cuerpo humano o animal vivo, el Coronavirus SARS-CoV-2 puede sobrevivir — no "reproducirse" - en las gotículas depositadas sobre superficies u objetos. Lo hacen durante períodos muy breves de tiempo que varían según el tipo de material (según la OMS, y aunque no es seguro que tenga capacidad para contagiar, puede sobrevivir hasta 72 horas en superficies de plástico y acero inoxidable, menos de 24 horas en superficies de cartón, y menos de 4 horas en superficies de cobre).

Contrario sensu, el Coronavirus SARS-CoV-2 "desaparece o muere" básicamente de tres maneras:

- De forma inmediata, al ser puestos en contacto con desinfectantes domésticos comunes, como jabón, lavandina o alcohol en gel.

- Luego de un período de tiempo, de permanencia fuera del cuerpo humano o animal, sobre las superficies u objetos (aunque no se lo ponga en contacto con desinfectantes).

- Luego de un período de tiempo, de permanencia y reproducción dentro del cuerpo humano o animal, por la propia acción del sistema inmunológico del organismo.

Sin pretensiones reduccionistas pero dimensionando asertivamente la cuestión, las personas tienen dos únicas acciones muy concretas a emprender:

A) Una acción respecto al Coronavirus SARS-CoV-2 existente en las gotículas depositadas en las superficies o manos: estas se pueden limpiar fácilmente con desinfectantes domésticos comunes que matarán el virus, o aislar de la presencia humana o animal a la zona u objetos, durante 24/72 hs. - dependiendo los tipos de material-.

B) Otra acción sobre el Coronavirus SARS-CoV-2 existente en las secreciones de personas o animales infectadas: debe evitarse que las gotículas "viajen" por el aire al ser despedidas por boca o nariz al ladrar, lambetear, hablar, 
toser o estornudar (con distintos tipos de obstáculos, como barbijos o codos flexionados, etc.), o dejando que viajen y se precipiten al suelo sin llegar a otras narices, bocas, ojos o manos; es decir, ubicándose a una distancia no menor a un metro. Eventualmente, claro está, no poniendo a las gotículas de las secreciones de terceras personas infectadas en contacto directo con las propias secreciones o nariz; sea por el contacto oral o físico; sea por el contacto de nariz, boca u ojos con objetos o partes del cuerpo - generalmente, las manos- depositarios de las gotículas con el virus.

Como puede observarse, sobre la base de su origen biológico y acción química, la posibilidad de sobrevivencia y transmisión del Coronavirus SARS-CoV-2 depende exclusivamente de los comportamientos humanos, convirtiéndolo en una cuestión eminentemente psicosocial y congruentemente, política.

Las medidas que se adoptarán en consecuencia y que se vieron de forma generalizada y masiva, son de dos tipos:

A) Aquellas destinadas a facilitar la adopción de las citadas dos únicas acciones de extinción del Coronavirus SARSCoV-2; y

B) Aquellas destinadas al control, relevamiento, acompañamiento, estímulo, asistencia y vigilancia del cumplimento de las mismas.

En cuanto a las orientadas a facilitar la adopción de las dos acciones descriptas, las medidas por excelencia que ha recomendado entre otros la OMS, han sido:

1) Desinfectar superficies y objetos de forma habitual.

2) Lavarse las manos a fondo y con frecuencia.

3) Evitar tocarse los ojos, la boca y la nariz.

4) Cubrirse la nariz o boca con el codo flexionado, pañuelo o barbijo o tapabocas.

5) Mantener una distancia de al menos un metro con las demás personas. 
Prácticamente todas las demás están orientadas a asegurar su efectividad mediante el control, relevamiento, acompañamiento, estímulo, asistencia y vigilancia del cumplimento de las cinco descriptas, o bien, a remediar o reducir los perjuicios o daños de su incumplimiento. Y los puntos de partida serán el abordaje de aquellas situaciones en que se considerarán "situaciones de alto riesgo de transmisión" o de mayor probabilidad; es decir, de ausencia de adopción de tales medidas.

La mayor probabilidad de que las personas no puedan desinfectar superficies y objetos de forma habitual, lavarse las manos a fondo y con frecuencia, evitar tocarse los ojos, la boca y la nariz, cubrirse la nariz o boca con el codo flexionado, pañuelo o barbijo o tapabocas en cada ocasión, o mantener una distancia de al menos un metro con las demás personas, se dan cuando concurren a estadios, teatros, escuelas, centros comerciales, lugares de trabajo cerrados y transportes públicos, entre otros espacios ampliamente masificados. Básicamente, en esas circunstancias y momentos, las 5 acciones descriptas son de cumplimiento casi imposible.

La reacción ante ello ha pivoteado sobre dos ejes:

A) La acción sobre las personas portadoras del Coronavirus SARS-CoV-2 en sus cuerpos para que en ningún caso entre en interacción con concentración de personas o espacios físicos cerrados en los que éstas puedan circular. Aquí se habla de "confinar" (encerrar, desterrar a un lugar que se convertirá en su residencia habitual y donde tienen que permanecer forzadamente) a estas personas en espacios físicos cerrados - preferentemente en una habitación individual de su hogar con su propio baño-. El confinamiento significa separar a las personas que están enfermas con síntomas de COVID-19 para evitar su interacción con el resto de personas y con el entorno físico en dónde se depositarían las gotículas infectadas. Es en toda regla una privación de libertad, con independencia de las medidas adoptadas para su cumplimiento y que su orden legitimante no se vincule con la seguridad pública o la persecución punitiva. 
La medida se procura de una duración de 14 días para provocar la desaparición o expulsión de la carga viral de SARS-CoV-2 por el transcurso del tiempo y la actuación del propio organismo.

B) La acción sobre las personas no portadoras del Coronavirus SARS-CoV-2 en sus cuerpos, con finalidades preventivas con diferente intensidad y temporalidad, consistió en la privación y/o restricción de derechos vinculados a las interacciones entre personas y su entorno. Obviamente, esta medida podría ser sustituida por pruebas masivas de laboratorio (los tests o hisopados) que acreditan la existencia o no de carga viral de SARS-CoV-2. Ello otorga además certeza y previsibilidad a la población y las personas, evitando tal restricción masiva de derechos.

A su vez, estas últimas han originado:

B.1) La prohibición de que ciertas personas no portadoras pero susceptibles o con alta probabilidad de serlo, interactúen con otras personas o circulen en espacios físicos potencialmente concurridos. Aquí se habla de "Cuarentena". Significa restringir las actividades o separar a las personas que no están enfermas pero que pueden haber estado expuestas a la COVID-19, con finalidades preventivas, durante el tiempo en que se podrían manifestar los síntomas de la enfermedad que denunciaría la presencia del virus en el cuerpo humano (en principio, también hasta 14 días). Igualmente, esta medida podría ser sustituida por la realización de las pruebas de laboratorio a una parte relativamente reducida de la población.

B.2) La regulación de densidades variables de concentración de personas en espacios abiertos o cerrados (regulación de la circulación según características de las actividades - esenciales o no esenciales-, proporciones según metros cuadrados de superficie por habitante, por bandas horarias, etc.). Aquí se habla de "distanciamiento 
social" aunque en realidad refiere a estar físicamente distante. La OMS recomienda mantener una distancia de al menos un metro con las demás personas. Es una medida general que todas las personas deberían adoptar incluso si se encuentran bien y no han tenido una exposición conocida a la COVID-19.

B.3) La prohibición de (asistencia a) actividades que conllevan alta concentración de personas durante un período de tiempo, como los eventos en estadios, teatros y escuelas, entre otros.

En conjunto, la lógica descripta es la que corresponde al "paradigma de la prevención por regulación de la movilidad o circulación desconcentrada de personas". No obstante, requiere la realización de las pruebas de laboratorio a las personas seleccionadas por su susceptibilidad de carga viral, y el acompañamiento y contención comunitaria en la salud mental de la población toda.

Esta es la medida estrella impuesta a los Estados durante esta pandemia: evitar o reducir la concentración de personas en espacios físicos cerrados eventualmente muy concurridos. Y, por extensión - solo por extensión- en los espacios públicos que son necesarios transitar hacia y desde esos espacios físicos cerrados.

\section{La circulación del virus: La humanidad inmovilizada}

Muchos Estados han apelado a otra manera de evitar o reducir la concentración de personas valorada - y valorable- de forma absolutamente disímil según las distintas posiciones sociales y políticas en que cada quien se encuentre: el denominado "Aislamiento Social Preventivo y Obligatorio" (ASPO), referenciado mediáticamente por el excluyente lema "\#Quedate en casa". El DNU 297/2020, en su parte dispositiva lo impone desde las 00 horas del día 20 de marzo de este año, y fija como condición para su respeto la permanencia en el domicilio o residencia habitual en la que se encontrasen a las 00 horas de ese día. 
Tal denominación comporta serios equívocos, ya que según sus formas de implementación la medida no conlleva "Aislamiento", porque se prevé el confinamiento en unidades de convivencia familiar. No es "Social", sino físico. No es "preventivo", sino anticipado a cualquier circunstancia a prevenir respecto de las conductas o sintomatología de las personas confinadas. No es "Obligatorio" sino prohibitivo, previéndose su transgresión —salvo los casos del amplio régimen de excepcionalidades- como parte de una acción típica del Código Penal.

La lógica del aislamiento, en todo caso, exacerba un dispositivo de control donde los sujetos son presentados como seres "aislados/as", negando la dimensión social de su existencia y proponiendo una "salvación individual" ante el peligro que implican los/as otros/as.

Insistimos, no es posible pensar al ser humano de una forma aislada; por ello en este trabajo consideramos que la sustantividad de la medida consiste en la inmovilización humana residencial masiva, por confinamiento en unidades de convivencia familiar.

En cualquier caso, la propuesta estatal de inmovilización humana o ASPO, es destacada como la medida principal a la que habrían apelado casi todos los gobiernos y autoridades del mundo (López Garrido, 2020). Además, la inmovilización debe interpretarse como un medio para lograr un fin; en este caso, evitar la socialización con concentración de personas sin distanciamiento físico, higiene personal y desinfección espacial.

La diferencia no es menor; si el fin es inmovilizar, el confinamiento en unidades de convivencia familiar parece ser la única vía apta para dejar de moverse durante un tiempo prolongado, y su transgresión hace a esas personas sospechosas de querer ir contra el derecho a la vida y la salud de todos. Si en cambio, el fin es evitar la concentración de personas, las medidas son múltiples. La inmovilidad puede ser incluso contraproducente (o hasta una invitación a la desobediencia), como en los casos en donde permanecer quieto o dejar de moverse, implica 
seguir estando masificado en una institución total. Pero sobre todo, lo que conlleva es una traslación en la meta a alcanzar: de evitar la concentración de personas —donde las medidas de distanciamiento, higienización personal y desinfección físicaespacial se hace muy dificultosa-, a lograr la inmovilización física de toda la ciudadanía, como fantasía, ideal, ficción jurídica y estrategia de control social.

De todas formas, una de las principales cuestiones a destacar se relaciona con el impacto en el principio y derecho a la integralidad de los derechos humanos. El DNU 297/2020 menciona el Artículo 14 de la Constitución Nacional, las libertades personales y los Tratados Internacionales, para justificar la posibilidad de restringir el ejercicio de derechos cuando mediaran -entre otras - razones de salud pública. Contando ya con algunos fallos judiciales que lo avalan, el Poder Ejecutivo Nacional ha resuelto múltiples privaciones y/o restricciones de derechos. En apariencia, ha quedado sujeto tanto al procedimiento legislativo previsto para los DNU como al estricto control judicial en su implementación. Todo, antes de una declaración de estado de sitio - que compete al Poder Legislativo- para limitar legítimamente los derechos que se ejercen en el espacio público.

Las restricciones de derechos, máxime si no hay estado de sitio ni conmoción interior declarada, debe ser la mínima indispensable para poder ejecutar aquellas medidas que se consideran inevitables, y por lo tanto, el examen de congruencia entre el fin y el medio utilizado debe ser constante. Un posible modo puede ser visibilizando de manera permanente que estamos en una realidad más que delicada en relación al ejercicio del poder para la restricción de derechos humanos, y no para su garantía. Desde esta perspectiva de derecho crítico se hace inevitable repasar - respecto de las principales medidas - cuáles han sido esas restricciones de derechos que se han adoptado. Luego, respecto a los fines declamados, cabe observar la proporcionalidad de las respectivas medidas y eventualmente, su correspondiente control judicial. 
En este sentido, cabe mencionar que se priva, impide o restringe sustantivamente el ejercicio de diversos derechos humanos básicos que se ejercen en dicho espacio público, como son los derechos políticos, derecho de asociación, derecho de reunión, derecho de protesta y de peticionar a las autoridades, derecho de participación social, derecho al hábitat, derecho a los cuidados de la vida humana en un ambiente sano, derecho a la recreación y el ocio, y especialmente, derecho a la convivencia comunitaria.

En particular, cabe resaltar que dicho confinamiento familiar se presenta en condiciones muy desiguales y que la mayoría de las veces implica también la imposibilidad del ejercicio del derecho al trabajo para quienes están en condiciones de mayor precariedad laboral. Ello profundiza aún más esas condiciones de exclusión y desigualdad, vulnerando de un modo casi inconmensurable el Artículo 14 bis de la Constitución Nacional y todos sus derechos derivados.

Quienes son partidarios/as de esta inmovilización parten de una premisa salomónica, pero bien sencilla: si todas las personas que habitan el planeta (y no solo las portadoras del SARS-CoV-2) permaneciesen quietas, inmóviles durante 14 días, a metro de distancia entre sí, desinfectando el espacio físico inmediato contiguo que habitan; toda la pandemia se detendría al instante. Se solucionaría el problema de la enfermedad de la COVID-19 e incluso la existencia misma del coronavirus SARSCoV-2 (Ramonet, 2020).

Su contracara, igual de radical, es aquella por la cual se debería inocular el virus a todas las personas del planeta, contemplar la supervivencia de las inmunológicamente más fuertes y asumir el nuevo estatus de inmunización colectiva. También, y como siempre, hay algunas elaboraciones mas moderadas, como las denominadas "inmunidad de rebaño".

Se estaría apelando además, de manera exclusiva - y casi excluyente de las cinco acciones referenciadas por la OMS - a una sexta y única medida: dejar transcurrir el tiempo necesario sin interacciones humanas físicas (generalmente, varias semanas 
más que 14 días) para asegurar la ausencia o expulsión del Coronavirus SARS-CoV-2 de todos los cuerpos humanos contagiados, sin rastros en ninguna superficie u objeto que pudiesen originar rebrotes.

Por supuesto, tal escenario de inmovilización humana total no es factible, pero su impulso será suficiente para contraponerlo al "paradigma de la prevención por regulación de la circulación desconcentrada de personas", pregonando otra perspectiva paradigmática en torno a la "inmovilización humana residencial masiva, por confinamiento en unidades de convivencia familiar". Como punto de partida ontológico y, a la inversa, la circulación desconcentrada de personas, el ejercicio de los derechos y la movilidad - a veces a cuenta gotas, en otras "fases", muy generalizadas- será la excepción y no la regla. Lo que pasa a regir es una lógica presuntiva de factibilidad de esta misma premisa: qué es lo posible o viable. Y lo mas parecido, posible y viable al "todo el mundo inmóvil, quieto donde está" es el confinamiento en unidades de convivencia familiar, en el entendimiento de que es dónde se puede "ubicar, parar o aquietar" a la gente.

Se pretende evitar la circulación de la gente, a la vez que se permanece en un lugar con reducida concentración de personas porque hay, obviamente, menos personas en cada unidad convivencial que en otras modalidades de convivencia o interacción comunitaria. Desde esta perspectiva de la Inmovilización, las mismas medidas de regulación de la circulación serán vislumbradas como "concesiones" excepcionales al "\#Quedate en casa" y la casa, hogar o vida y convivencia familiar, pasarán a ser el lugar normalizado de existencia y permanencia. En cambio, la restricción a la vida social en la calle, el espacio público y convivencia comunitaria — donde la grupalidad nuclear familiar es solo una de las que la integran-, reforzarán la implementación de medidas de "excepción". La restricción de derechos continuará siendo la regla y las políticas represivas y de control policiales seguirán siendo las principales herramientas que el Estado establece para "combatir" el virus o el "crimen" del incumplimiento. 
Evidentemente, esta medida conlleva una manera de interpretar y de hacer efectiva la desconcentración de personas con SARS-CoV-2; no solo la gente - toda la gente- evitaría concentrarse con otras personas, sino que nadie transitaría el espacio público.

Ante esto, caben replantearse las preguntas de la gran disputa global que se viene señalando con el objetivo de comprender cuál es la capacidad que tiene un Estado democrático para dar respuestas a una pandemia como la que estamos atravesando - o cualquier otra- en el marco del enfoque de inclusión por el ejercicio de derechos que debe caracterizarlo. Y también, indagar en la potencial reacción ante los diversos modelos comunitarios de resistencia social que buscan, justamente, salir de ese modelo único y hegemónico de integración social estratificada.

Pero aquí no acaba la cosa. Porque esta medida genérica, masiva e indistinta de profunda, estructural y transversal restricción de derechos, tiene en sociedades plurales y profundamente desiguales, algo más que importantes excepciones a su homogeneidad práctica. Si en términos biológicos la enfermedad COVID-19 puede afectar por igual a todas las personas sin distinción, no se producirá ni distribuirá de igual forma la respuesta médico-sanitaria de las personas enfermas, ni la transmisión del Coronavirus SARS-CoV-2 circulará de forma homogénea entre las personas, grupos y territorios sometidos a fuertes desigualdades sociales por razones de clases, sexo-genéricas, etarias y étnico-nacionales, residenciales y socio-vinculares, entre otras. Por eso, insistimos, si el virus no discrimina entre clases sociales, el estado y sus políticas públicas, por acción y por omisión, sí.

\section{Regulación de la Inmovilización Humana Residencial Masiva. El poder siempre vacía la calle}

Para empezar a responder sobre la capacidad que tiene un Estado democrático de intervenir desde un enfoque de ejercicio de derechos ante una pandemia, debemos comenzar por abordar el colosal dispositivo de control social actualmente existente. En 
efecto, no hacía falta ningún virus para saber que la población de una ciudad sólo puede ser radicalmente controlada a través de la prohibición o restricción de circular libremente por las calles de esa ciudad. Esta práctica no es novedosa, existe hace siglos y suele llamarse "toque de queda". Lo que parece variar son las razones que lo permiten y su consenso. La cultura y el discurso del miedo se combinan con las lógicas de la otredad como peligro, como enemigo. Siempre actualizando los discursos pero sin modificar la esencia de sus estrategias.

En primer lugar, observamos discursos liberales que exacerban el goce irrestricto de derechos individuales sin ningún tipo de injerencias estatales o comunitarias. La más clásica de sus reivindicaciones ha sido el derecho de propiedad individual frente a gravámenes de políticas tributarias o respecto de la función social de la propiedad colectivizada. Aunque también los ha sido el derecho a la movilidad.

En segundo lugar, surgen las denuncias de sectores del comunitarismo y el realismo marginal sociológico. Las libertades individuales que - en apariencia parecer - teníamos, no rigieron nunca ni rigen para los sectores más vulnerabilizados. Estos sectores protestan de manera vehemente contra la centralización, la concentración y la personalización del poder público que, a su criterio, implementan amplias y generalizadas restricciones de derechos individuales homogéneos y de incidencia colectiva. Proponen, en cambio, formas de democratización, de contención y de resolución comunitaria, a partir de políticas que sean representativas de las asimetrías territoriales, interseccionales y materiales realmente existentes en la diversidad de grupos sociales (Di Nella, 2006).

En tercer lugar, existe un amplio sector de la sociedad con un alto grado de acatamiento de las medidas -incluso por aquellos sectores que podrían ser identificados como los más perjudicados/as - De una manera u otra, estos sectores piensan que todo esto vale la pena padecerlo porque el peligro es real. La lógica parecería ser: hay un virus y si no se pone en juego la propia existencia por inanición, no hay que salir. Se padece el 
asilamiento domiciliario, la restricción dineraria, la pérdida de la fuente laboral mercantil; pero se intenta soportar el mayor tiempo posible por miedo de transmitirse el virus.

Para lograr el cumplimiento de la inmovilidad, básicamente se opta por el amedrentamiento social. Se escucha por todos los medios, la producción de estadísticas oficiales y no oficiales (de base científica muy endeble) con la cantidad de muertes y la cantidad de contagios, es decir, la cantidad y el peligro inminente que hay fuera del acatamiento de las medidas. Los discursos patrióticos de salvación, dirigidos a prácticas de salvación individual y de equilibrio personal, serán la herramienta para instalar la bondad de "\#quedate en casa" que "nosotres" desde el Estado nos vamos a ocupar.

Los discursos exacerbarán la capacidad destructora que tiene el virus y la peligrosidad que implica circular en los espacios públicos. Construirán la hegemonía del peligro de la calle; históricamente, los espacios de disputa política, de lucha social, de organización comunitaria, de encuentro vital. Es justamente ese espacio público —el mismo de la resistencia y lucha social—, donde está el peligro, el virus, ese "bicho" casi corpóreo, humanizado, bíblica y bélicamente erigido en un enemigo invisible. Un virus que acecha afuera, en los tradicionales espacios de solidaridad comunitaria, en las calles y plazas que pensábamos siempre de las madres y el pueblo pero que (¿ahora?) amenazan con políticas de limpieza ciudadana practicada por policías y militares (Almeda Samaranch, 2020).

El discurso hegemónico dirá: "Estamos en guerra contra el virus". Por lo tanto, se impone la necesidad del mayor aislamiento social como salida individual del conflicto a partir del confinamiento domiciliario y familiar. Se azuzará la idea de que hay "un algo" en la calle; metáfora inconclusa del "algo habrán hecho" (pero, para la progresía, esta vez real) que hace que no tengamos que circular ni articular nada fuera de nuestros seguros hogares más que la "vigilancia social" del cumplimiento de la cuarentena. 
La clase gobernante, por su parte, lo aprovecha para jactarse del éxito de las medidas de confinamiento, no necesariamente por méritos propios, pero sí por su popularidad. En cualquier caso, puede percibirse en ello cierta narrativa cuasi religiosa, que pretende legitimar (o construir) los consensos en torno a modelos securitarios y/o tecnocráticos de control social. No se trata de una normalidad exacerbada de la desigualdad social en las situaciones de excepción expuestas; nos encontramos de forma palmaria, desinhibida y transparente, ante realidades preexistentes que usualmente permanecían subyacentes, implícitas, anestesiadas, atemperadas, edulcoradas en discursos obicuos de posiciones en apariencia componedores. Por ello, afloran con mayor puridad y acritud, la bondad y la maldad, la osadía y el temor, la solidaridad y el egoísmo que cada quien ya practicaba con anterioridad, sin conversión alguna (Sztajnszrajber, 2020).

\section{VI.1. Modelos sanitaristas tecno/securitarios, de control del cumplimiento de la Inmovilización Humana Residencial Masiva}

Frente a los modelos intersectoriales de salud comunitaria encontramos diversas variantes de los modelos sanitaristas tecnocráticos y securitarios. Estos se presentan a sí mismos como la voz de "autoridad", portadora de "la verdad", configuradora de la ciencicracia, escenificada en los llamados "expertos" y "especialistas". Reproduciendo los tradicionales paradigmas del positivismo clásico con una mirada absolutamente biologicista de la salud, negando sus dimensiones socio-económicas y políticas.

Sin embargo, ante la Pandemia de la COVID-19, no hay aún una sola posición científica, ni un consenso básico sobre aspectos fundamentales de las cuestiones en juego. Prima la incertidumbre, abatiendo las verdades absolutas y de control humano sobre la "naturaleza". Nuevamente se derrumba, como lo han hecho a lo largo de la historia, la creencia absoluta en el poder y en las "certezas de la ciencia".

Por otra parte, en casi todo el mundo hay un enfoque "reduccionista" del saber sobre el virus en general y del saber 
científico en particular. Una prueba cabal de ello es la permanente remisión de los gobernantes a unas pocas disciplinas (Epidemiología, Virología, Infectología y Medicina) dejando afuera o minusvalorando las ciencias sociales y humanas (Psicología, Sociología, Demografía, Geografía, entre otras) indispensables para abordar lo que se ha reconocido, es un tema claramente psicosocial, de comportamientos humanos (Aranda, 2020).

Estos modelos tecnocráticos se combinan estrechamente con diversas variantes de los modelos securitarios donde la salud pasa a ser parte de las lógicas de vigilancia-control y no de la prevención-promoción. Así, la salud entra en un campo donde el otro/a es lo peligroso. Lo cual requerirá, además de la "ciencia", construir dispositivos que mantengan a ese riesgo alejado y controlado para "protegerse" del virus.

Por otro lado, es paradigmático el desdén hacia las múltiples formas de conocimiento y saber popular que estos modelos proponen. Esta invisibilización aparece como respuesta en el marco de las dinámicas socio comunitarias de regulación de la conducta humana, que han sido totalmente marginalizadas. Recordemos además, que los pueblos naciones originarios, en el marco de su derecho a la autodeterminación, tienen el derecho a asumir las prácticas estatalistas de conformidad a sus propias culturas y formas de organización política, social y sanitaria ancestral.

Frente a estos modelos, el de la intersectorial de salud comunitaria afirma que el estado de salud-enfermedad, tanto a nivel individual como social, resulta de la interacción de factores que se abordan de manera interdisciplinaria e intersectorial (comunidad, estado y privado), operando jerárquicamente en diferentes niveles de determinación. Existen determinantes básicos a nivel sistémico (ambiente, genoma, etc.), determinantes estructurales a nivel socio-estructural (estratificación social, mecanismo de redistribución de la riqueza, etc.), determinantes próximos a nivel institucional-familiar (estilos de vida, sistemas de salud, etc.) y determinantes a nivel individual (el propio 
estado de salud). La principal ventaja de esta propuesta es que propone un enfoque integral para el estudio de los determinantes del proceso que incluye los factores demográficos, epidemiológicos, económicos, sociales, políticos, etc. (Frenk et al., 1991; Arredondo, 1992).

Aun así, la primera reacción de la gran mayoría de los Estados ha sido claramente la de apelar al modelo securitario clásico dentro del discurso de la defensa o "salvación nacional”. En efecto, durante la pandemia surgió con intensidad el nacionalismo y el salvacionismo en defensa y en nombre de la patria. Sin embargo, el nacionalismo no es sino un sentimiento de adhesión a un territorio, su memoria histórica y su pueblo, al que puede dársele sentidos diversos y hasta antagónicos. Las ideas de nacionalismo relativas a la adhesión a una tierra y a un paisaje — sobre la base de una historia común, que acaban forjando una identidad compartida como pueblo naciónson inevitables. Es una manera de concretar sentimientos y pensamientos que permiten tener cosas en común con otra gente - y a menudo es la única que se posee-. No es, por tanto, ni de derechas ni de izquierdas per se; puede estar al servicio de fuerzas políticas e históricas totalmente distintas.

Ahora bien, esa publicitada necesidad de salvarnos entre todos y todas, implicará el cumplimiento de una serie de pautas muy restrictivas de los derechos, determinada por el propio Estado. También, va a posibilitar que ciertas personas de carne y hueso traduzcan esas pautas estatales en decisiones personales con capacidad de incidir política y socialmente en el conjunto de la sociedad. Ese decisionismo centralizado de los procesos hecho en nombre de la defensa nacional es el que va a ir definiendo la oportunidad, justicia, gradualidad, espacialidad e intensidad de la Inmovilidad humana residencial y sus efectos en millones de personas.

En este sentido, puede observarse en los análisis la construcción de una narrativa cuasi apocalíptica, estructuralmente religiosa y securitaria; que viene a acentuar cierta predisposición social a consensuar teórica y fácticamente con las medidas 
adoptadas para hacer frente al peligro real de transmisión comunitaria del virus. En efecto, el acatamiento masivo al confinamiento domiciliario, el disciplinamiento personal, el control y vigilantismo vecinal, la alta tolerancia a la militarización del espacio público y a la punición de la transgresión y la reproducción de la victimización y vulnerabilización de los grupos sociales marginalizados; son solo algunos ejemplos que permiten vislumbrar hasta que punto las estrategias de abordaje de la pandemia y la inmovilización humana residencial masiva responden a comportamientos sociales que presentan grandes consensos sociales y políticos.

Así hemos visto, por lo menos en las primeras semanas, un período de entendimiento político y colectivo en torno a dichas medidas. Ello pudo estar vinculado a la rápida reacción del gobierno para la construcción de un consenso social con todos los sectores que lo apoyaban y apoyan, pero también de sectores de la oposición con responsabilidades de gestión pública. Tal legitimidad se edifica en la eficacia y eficiencia de la gestión estatal como gran actor para capear la crisis pandémica (recordemos además, que esta realidad aparece en el marco de un gobierno muy nuevo a solo algunas semanas de su asunción).

Por supuesto, ello no quiere decir que ciertos sectores del activismo social no salgan especialmente fortalecidos o legitimados. Por ejemplo, aparece consolidada en todo el arco político ideológico la necesidad de una política de salud pública preparada para el abordaje en situaciones extraordinarias de incidentes críticos, desastres o catástrofes (Di Nella y Yacachury, 2018). Del mismo modo, se han hecho palpables la legitimidad de las reivindicaciones de los movimientos ambientalistas vinculados a la interdependencia del hábitat y la sanidad planetaria. También, en tanto que la salud es un acontecimiento político y a la vez personalísimo, se ha hecho evidente la legitimidad de todos aquellos movimientos sociales que, como los feminismos, venían postulando que lo político no se reduce a los aspectos macrosociales o estructurales, sino que se juega en el plano de lo personal -incluso de lo 
íntimo - en nuestra cotidianidad y en la operatividad concreta de nuestras relaciones vinculares.

No obstante, no debería sorprender la transversalidad ideológica que sostiene las medidas estatales mas restrictivas del ejercicio de los derechos. En realidad, hasta los sectores más neoliberales concuerdan con la necesidad de un Estado gendarme (de amplia presencia policial y militar en el espacio público) con una intervención social subsidiaria, justamente, focalizada en las extraordinarias situaciones críticas, desastrosas o catastróficas que puedan surgir — si cabe, como meras fallas del mercado a corregir o reorientar-. En ningún caso ello implica una hegemonía neo-social-demócrata o neo-keynesiana sino más bien sus mínimos comunes denominadores con el neoliberalismo. Las características de esos mínimos comunes - sedimentados en las prácticas burocráticas de los Estados desde hace décadas- son los que engendrarán, tal como venimos comentando, los dos modelos o variantes de gestión tecno-securitaria del derecho a la salud (el modelo sanitarista tecnocrático y el modelo sanitarista securitario). Estos modelos siempre mantienen su predominancia, aunque sea rotando en su coexistencia - a veces de forma complementaria, otras articulándose y en ocasiones sucediéndose entre sí durante diversos períodos-.

\section{VI.2. Participación ciudadana y control social}

La necesidad de una mayor participación para el desarrollo de un control social mas estricto en el contexto sociopolítico actual fomentó la participación ciudadana en esta "guerra de todes contra el enemigo invisible" (así dicho, con lenguaje inclusivo, pero en las antípodas ontológicas de su sentido). En efecto, la presencia de la ciudadanía en la acción de control del espacio público — que tradicionalmente ha sido asignada al Estado- es recogida por dos corrientes de pensamiento político muy disímiles (Aniyar de Castro, 1999):

a) La concepción política de la globalización-descentralización presupone el debilitamiento del Estado en beneficio 
de la desregulación de las relaciones sociales y económicas, reduciéndolo a cuestiones básicas o estratégicas (defensa de fronteras, impuestos, legislación, etc.). También, conlleva un deslizamiento del control interno de la vida social y de la solución del mayor número de necesidades y conflictos hacia los gobiernos locales, las comunidades y el sector privado.

b) La concepción avanzada de democracia social (la democracia participativa) parte de que el despliegue de la energía social es una forma de perfeccionar la democracia. La participación en la gestión y la toma de decisiones de las políticas sociales se consideran fundamentales. Se revalorizan estos espacios de acción para mejorar las respuestas a las necesidades sociales desde la propia cosmovisión del mundo de las personas que habitan el territorio (generalmente locales).

La convergencia de posturas políticas tan disímiles es una ventaja para la aceptación generalizada de medidas como el control vecinal para el cumplimiento de la inmovilización residencial por amedrentamiento o simple represión. Estas formas de participación vecinal suelen degenerar en atropellos de carácter antidemocráticos, como hostigamientos, ciberacosos, reclamos de expulsiones de edificios y formas de justicia por mano propia, entre otras. En situaciones extremas han llegado traducirse en cercas electrificadas, uso de perros asesinos, linchamientos, homicidios por encargo, escuadrones de la muerte y otras formas de violencia extralegal.

También entrarían en estas prácticas los llamados al público para conseguir detenciones. Desde los modestos "autoridades solicitan ayuda para perseguir a un fugitivo" hasta las "recompensas" con premios que mercantilizan el deber ciudadano de no ocultar el conocimiento de un delito o la presencia de la persona transgresora. Precisamente, para evitar la "participación vigilantista" se debe prever un buen sistema de participación controlado dentro de los límites legales.

Por ello, insistimos, debe actuarse con mucha prudencia ante mensajes potencialmente "confusos", como los de policializar y 
militarizar el espacio público o invocar al vigilantismo vecinal. Por ejemplo, los modelos de control y denuncia vecinal durante el confinamiento se expresaron en medidas de 0800 para que la gente llame y denuncie a sus vecinas y vecinos que no estarían cumpliendo la cuarentena. Otro ejemplo son las nuevas sanciones, multas y secuestros de vehículos — transferidas al nivel local-; formas múltiples de control informal, formal y punitivo-represivo como medio de construcción de modelos de ejemplaridad social.

Por otro lado, encontramos los mecanismos de inteligencia digital que van desde la geolocalización y rastreo de dispositivos móviles de las personas en cuarentena, al uso de aplicaciones móviles destinadas al control de todas las personas en sus movimientos. Este modelo de inteligencia reproduce el autodenominado "ciberpatrullaje", consistente en la manipulación de millones de datos privados, íntimos o personales que lesionan masivamente múltiples derechos. Aún es una incógnita lo que harán con esa big data mundial. ¿Realmente hay capacidad algorítmica o humana para ejercer ese control en tiempo real de nuestras vidas?. Edward Snowden afirma que la cibervigilancia no pretende un rastreo en directo de determinadas personas o sectores sociales sino la construcción de una big data que permita actuar expost. Cuando resulte estratégico destruir a alguien en particular, podrán utilizar en su contra todo lo que ha realizado durante años en el móvil, las redes y el correo.

Tal circunstancia no parece ser sino la actualización histórica de mecanismos de muy antigua data. Las noticias falsas, el lawfare, las denuncias arbitrarias y hasta la brujería responden al mismo patrón de control por argumentación retórica sobre la base de verosímiles y no de persuasión por pruebas o evidencias. Una vez más, ciertos mecanismos, como la video-vigilancia cibernética, no son nuevos modelos de control y represión. Pensemos, por ejemplo, en las enseñanzas que nos legó hace décadas Pink Floyd.

En cualquier caso, no podemos desentendernos de los efectos sociales de la percepción compartida de vigilancia total y permanente sobre nuestras vidas. Tal como sucedía con la 
selectividad penal para el amedrentamiento, hoy veremos estas prácticas en testeos cibervigilantes; cuentan incluso con programas televisivos que propagandizan la eficacia del instrumento de control remoto de fechorías de malandras y afines, por medio de la camarita o las redes sociales.

En la masividad de la orquesta mundial de los datos en red tal vez la clave está, pese a la herida narcisista que pueda provocarnos en nuestra vanidad, en que no le importamos tanto a nadie o le resultamos absolutamente inofensivos. Por eso, aun disponiendo de la capacidad tecnológica para hacerlo, nadie nos vigila. $\mathrm{Y}$ cuando lo hacen, con la disidencia social activa están haciendo lo de siempre, solo que por otros medios (Delgado, 2020). Ese es el auténtico control: nos espían y controlan al modo y con los recursos del siglo XXI pero como siempre; o no nos espían en ningún modo pero hacen que creamos que sí. Entonces, logran un verdadero control e inhibición popular, incluso la autoindulgencia en la valoración y justificación de la propia pasividad ante lo injusto o la hiriente desproporcionalidad de la desigualdad.

Sea con la represión policial y militar, con modelos de inteligencia artificial o con formas de vigilantismo social; estos discursos y prácticas del miedo provocarán un aumento del estrés y de la angustia a partir de la construcción de una calle absolutamente peligrosa, hostil. Ello acabará amedrentando a toda persona que intente diferentes tipos de salida comunitaria o no-estatal de la pandemia. El desafío es entonces, desarrollar medidas eficaces para evitar la concentración de personas que reproduzcan la transmisión de la COVID-19, a partir de la menor restricción posible de los Derechos Humanos.

\section{VI.3. Restricción de derechos para el abordaje virológico. La construcción de la categoría de "sospechoso"}

Uno de los constructos que más limita la menor restricción posible de los Derechos Humanos es la categoría de "sospechoso". En primer lugar, esta refiere a una realidad biológica, 
es decir, a un indicador de carácter probabilístico que indica la susceptibilidad de incorporar o haber incorporado en el propio organismo el virus SARS-Cov-19. En términos biomédicos, dicha susceptibilidad está relacionada con la noción de riesgo; en virtud de su estructura genética un individuo es más o menos vulnerable a una exposición ambiental desencadenante. Como en toda "sospecha", hay indicadores que no prueban pero sí construyen indicios de verosimilitud de portación del virus. En este caso, los principales son tres:

a) los síntomas en la propia persona;

b) los síntomas o pruebas de terceras personas con las que no ha mediado el distanciamiento social o se han compartido espacios físicos cerrados; $\mathrm{y}$

c) la presencia en "zonas afectadas", consideradas tales por la existencia de transmisión comunitaria o masiva del virus en esos espacios físicos o territorios.

Como puede observarse, ninguna de las tres instancias que ubican —en términos médico-clínico-epidemiológico- a una persona determinada como "sospechosa" derivan de actos voluntarios de la misma. Son en cambio, consecuencia directa de la propia biología y característica propagación viral del SARS-Cov-19. Sin embargo, la construcción de la "sospecha" transita - por analogía y/o extensión semántica- hacia el lenguaje jurídico y mediático, como sospecha de comisión de un hecho delictivo o una transgresión legal o del deber ser. Si se es sospechoso de portar el virus, se es sospechoso de no haber realizado voluntariamente los comportamientos que, hipotéticamente, podrían haberlo evitado. Extremando este razonamiento, puede afirmarse que quien no permanezca inmóvil en su domicilio o allí en donde esté, a un metro de distancia de otro sujeto y con desinfección del espacio circundante, es también un "sospechoso" de querer contagiar el virus. Esta construcción metafórica de la preterintencionalidad u obrar cuasi-temerario, permitirá afirmar que la simple movilidad es "ir a buscar al virus" lejos del confinamiento residencial de nuestras casas. 
Ante estos ojos, entonces, todas/os somos construidos y presentados -incluso jurídicamente- como sospechosos de propagar el virus, no como consecuencia de lo que hacemos (eventualmente, movilizarnos o circular por la calle) o somos (sujetos de derechos viviendo en sociedad), sino como meros cuerpos $\mathrm{u}$ organismos biológicos con capacidad reproducir y trasmitir comunitariamente el virus. Siendo además un virus que enferma y mata al ser humano, el movimiento de nuestros cuerpos es hasta un arma mortal.

La deriva argumentativa aquí escogida puede tener ribetes cinematográficos, pero no por ello deja de responder al perfil criminológico-mediático que se presenta. En este sentido, cabe mencionar a las personas que provienen de los márgenes de la "sospecha": laborantes precarizados, trabajadoras/es en la vía pública, trabajadores/as de la sanidad pública (reiteradamente víctimas de acoso domiciliario o callejero) personas en situación de calle, residentes en instituciones totales que salen de ellas, repatriados o migrantes de zonas afectadas, convivientes con esas personas, entre otros/as.

Es cierto que la portadora y transmisora potencial del virus es la persona en movimiento, pero lo que determina la posibilidad de contagios son ciertas formas de socialización e interacción entre personas. Lévinas (1993) afirmaba que el encuentro con las/os otros/as es la captación de una experiencia de alteridad y de trascendencia. Lacan (1968) lo desarrolló como el conocimiento paranoico del mundo en el encuentro con el/la otro/a. Es ahí donde las personas se topan con este temor al vecino/a, sea conocido/a o no. El otro/a es sospechoso en su búsqueda de libertad, la percepción de una pequeña diferencia en la alteridad le arroja inmediatamente en la categoría de aquellos de quienes se debe desconfiar. En consecuencia, estas formas de socialización e interacción vienen sobre-determinadas por factores objetivos, subjetivos, roles y estatus que conforman las posiciones sociales en la estratificada estructura social. 


\section{Desigualdad y grupos vulnerabilizados por la IHRM}

A esta altura puede parecer una verdad de perogrullo que la pandemia ocasionada por el virus SARS-Cov-19 y la enfermedad humana que ocasiona no ha hecho más que retratar - con una dosis de crudeza más alta de la habitual- las enormes desigualdades que configuran a las sociedades humanas. En cambio, la adopción de la Inmovilización Humana Residencial Masiva (IHRM), no ha hecho mas que reproducirla y acrecentarla.

Robert Castel (1997) sostenía que el término exclusión pretende denominar lo que no se puede nombrar, es decir, la falta de palabra que unifique la crueldad. Se dice que el virus no discrimina clases sociales pero parecería que el Estado sí. La Inmovilización Humana Residencial Masiva y la implementación de modelos de control social autoritarios para su cumplimiento ha sido su gran corroboración. En efecto, el mismo Estado que debería garantizar derechos es el que al mismo tiempo reproduce la violencia de la exclusión, de la invisibilización. Ello inevitablemente debe ser entendido como parte de los procesos políticos y sociológicos que conllevan una serie de realidades de vulnerabilidad asociadas, entre otras cosas, a la feminización de los cuidados de la vida humana, el racismo, la xenofobia, la violencia, los prejuicios sociales, la pobreza, el aislamiento socio-vincular y otras grandes desigualdades en el acceso y ejercicio de derechos.

Esas desigualdades son, además, constructos interseccionales que atraviesan la vida de las personas, sus prácticas sociales y sus instituciones, afectando el acceso a derechos y oportunidades. Dicho de otro modo: clase, género, generación, etnia, nacionalidad, estatuto migratorio (entre otras variables) se cruzan y configuran el impacto de toda medida estatal implementada de forma generalizada en toda la población. La propia consigna "\#Quedateencasa" ha sido una decisión estatal que ha revictimizado a grupos ya vulnerabilizados en sus derechos, condenándolos a la intemperie, a un dejar morir, donde el propio Estado decide quien importa y quien no (Mbembe, 2003). 
Ello se expresará en sucesivos niveles de opresión que afectarán especialmente a determinados sujetos en los que confluyen más de una de estas categorías, como si fuesen capas de una misma cebolla. Recordemos: lo que no está expresamente regulado a favor de la parte mas débil de la relación de poder, está implícitamente regulado a favor de la parte más fuerte.

Sin pretensión de agotar el abordaje de las distintas realidades de desigualdad y exclusión, creemos necesario mencionar algunos de esos impactos diferenciales en los diversos colectivos especialmente vulnerabilizados.

\section{VII.1. Personas confinadas en unidades de convivencia familiar}

Esta es la medida por excelencia de los gobiernos, para evitar la concentración de personas. Supone que la convivencia familiar siempre tiene una concentración de personas menor que las dinámicas de interacción en espacio público. Por lo tanto, la idea es sacar a la persona del espacio público, confinándola en espacios de menor concentración de personas. Igualmente, muchas veces hemos visto cómo el domicilio "real" que nos obligan a declarar (pretendidamente único y personalísimo), no se corresponde con nuestra/s residencia/s cotidiana/s. Esto presume el desarrollo de la convivencia familiar armoniosa y, sobre todo, la obligación de permanecer en un único lugar durante todo el confinamiento. Incluso, durante el comienzo de la medida, se estableció el deber de permanecer en el lugar en el que se hallaba a las 00.00 horas del día 20 de marzo de 2020 - momento en que entró a regir el primer DNU sobre la materia-.

La medida presupone otras cuestiones subyacentes, como que todes convivimos en familias nuclearizadas, o sostenemos las estrategias capitalistas de producción de renta de la misma forma. En efecto, la inmovilización residencial que propone el Estado parte de esas simples falacias, porque imagina un hogar, modelo familiar y arquitectura habitacional de tantos metros cuadrados y habitaciones por residente. Parte también de la presunción de que este confinamiento se desarrolla en equilibrio 
psíquico; y para cuando no sea así, propone como alternativa una serie de actividades domésticas -básicamente, "ocupar el tiempo" y entretenerse- que drenarán y auto-depurarán los aspectos adversos del proceso de aislamiento físico y vincular.

La movilidad residencial de ninguna manera puede ser reducida o asimilada a un privilegio de los sectores de clase alta o integrada de la sociedad, para su mayor ocio y esparcimiento. Solo puede verlo así, un Estado que se dirige a una sociedad auto-referenciada en esos sectores. Por el contrario, si se mira desde abajo, observaremos que las estrategias de crianza y desarrollo de los sectores mas pauperizados se caracterizan por una menor adhesión a la residencialidad única o a una nuclearización de los modelos de crianza. Al desarrollar una mayor comunitarización de sus relaciones sociales y afectivas, una medida de confinamiento domiciliario penaliza especialmente a estos colectivos, con un impacto claramente diferencial en cada uno de ellos (Almeda Samaranch, Camps, Di Nella y Ortiz, 2016).

La inmovilización residencial por confinamiento en unidades de convivencia familiar, ni siquiera existe en el caso de las personas en situación de calle. La consecuencia de la medida no fue otra que su represión y linchamiento social. Esto, en el marco de una exacerbación de los estereotipos vinculados a una supuesta voluntad transgresora de estas personas. En definitiva, en ningún momento fueron previstas ni asumidas como prioritarias las personas en situación de calle, para darles una respuesta que no implique la mayor exposición a la transmisión del virus.

Cabe destacar que otro sector afectado de modo excesivamente desigual con la imposición estatal de "quedarse en casa" ha sido el de las mujeres. Respecto a las desigualdades en los modos de distribución de los cuidados de la vida humana, la consecuencia fue la revictimización de las mujeres y la suprafeminización de los cuidados. Ello no solo ocurrió en los grupos familiares, de pares y comunitarios, sino también en sus lugares de trabajo mercantiles, especialmente de aquellos que se desarrollan en la vía pública, como las ventas ambulantes y los servicios sexuales. 
Por otra parte, la convivencia forzosa en unidades familiares, necesariamente potencia exponencialmente el riesgo de padecer las violencias machistas, pero sobre todo restringe la posibilidad de articular estrategias e interactuar en las redes comunitarias; muchas de las veces, las únicas mallas de contención y sostén de estas mujeres. Este modelo ficticio de convivencia familiar, lo único que hace es continuar reproduciendo las condiciones de violencia patriarcal.

Las estadísticas dan cuenta de una alta tasa de femicidios y travesticidios. “...En lo que va del 2020, del 1 de enero al 5 de abril son 100 los femicidios y travesticidios confirmados: 85 mujeres y niñas, 15 travestis y trans. Entre el 1 de marzo y el 4 de abril fueron halladas 28 mujeres, niñas y travestis víctimas de femicidio o travesticidio, según el relevamiento de organizaciones sociales y ONGs a partir de noticias en los medios de comunicación o publicaciones en redes sociales. No hay datos oficiales. Desde el 20 de marzo, cuando empezó la cuarentena obligatoria por coronavirus, fueron encontradas o asesinadas casi la mitad: 16 mujeres, niñas y travestis muertas por la violencia machista...". (Lavaca, 2020).

Así, el "aislamiento" es el escenario perfecto para el despliegue de las violencias machistas, un escenario que permite cumplir deseos arraigados de los violentos: controlar, someter y anular socialmente a las víctimas. Así, entonces, las vulnerabilidades y desprotecciones se expanden.

Por otro lado, recordemos que ante el confinamiento familiar, el derecho a la libre elección de la convivencia familiar es uno de los más vulnerados, porque no puede ser autodeterminado y autogestionado. El lugar de confinamiento y la modalidad de convivencia en que se realizará, está impuesta por el estado; ello no solo restringe los derechos sino que además reproduce la desigualdad.

Por último, si la única modalidad convivencial prevista es la nuclearización familiar en la vivienda de residencia habitual y no hay otras posibilidades a considerar, es porque se parte 
de dos grandes presunciones: las personas no se mueven ni cambian de lugar, y tampoco tienen posibilidad ni necesidad de desarrollar interacciones convivenciales con otros sujetos que no sean las del núcleo familiar parsoniano.

\section{VII.2. Mujeres monomarentales, tiempos y trabajos totales}

Las tareas de cuidado recaen mayormente en las mujeres. Ello está ampliamente contrastado en la literatura con perspectiva de género - especialmente la derivada de los feminismos-, así como en la experiencia vital de quienes han sido socializados/as en grupos de convivencia androcéntricos —en una sociedad patriarcal, casi todas las personas que no transitan por las disidencias sexo-genéricas-. De este modo, las circunstancias del hogar y la desigual distribución de las tareas domésticas de cuidado repercuten de forma muy negativa en las posibilidades de empleo femenino, en su fortalecimiento y promoción (Di Nella, Almeda Samaranch y Ortiz, 2014).

Esto es más grave durante períodos de confinamiento en unidades de convivencia familiar, donde más que nunca, se exige cuidado de las personas en construcción de sus autonomías relativas —niñes, mayores y en general, personas dependientes en el hogar-. Resulta obvio que si están encerradas todo el día o gran parte de él (sin acceso a escuelas, centros de día, etc.) sus necesidades son aún más elevadas y complejas.

Asimismo, las mayores exigencias de cuidados en el hogar acaban afectando las posibilidades promocionales del laboro mercantil, especialmente en el caso de mujeres sobreexplotadas en tareas domesticas y de cuidado remuneradas.

Definitivamente, la gestión de los tiempos y trabajos totales (de cuidados de la vida humana, y de empleo mercantil) en esta época de pandemia se torna un puro malabarismo femenino, pocas veces asistido por los servicios públicos o equilibrado con las responsabilidades de cuidado que también tienen sus homólogos masculinos. En este sentido, hay que tener en cuenta a las familias monomarentales —donde la mujer es la 
principal responsable del hogar y convive con sus hijas e hijos sin grandes apoyos o ayudas en su vida familiar cotidiana (Di Nella, 2017)-. En esos casos, la mujer adulta debe asumir sola la responsabilidad de la gestión de todas las tareas de cuidado de las personas confinadas - y muchas veces, gran parte de la realización de las propias tareas-. Ya de por sí, las monomarentalidades engrosan los grupos familiares más pobres y vulnerables de la sociedad. Cuando la mujer esta empleada en trabajos mercantiles esenciales que la fuerzan a laborar fuera del domicilio familiar - relacionados con la salud, la limpieza sanitaria y la alimentación, generalmente en condiciones de precariedad - la situación se agrava todavía más; son pocas o nulas las posibilidades de conciliar los cuidados y trabajos no remunerados y los trabajos remunerados. Y si la mujer está empleada en trabajos mercantiles que la fuerzan a diferentes modalidades de teletrabajo, se ven resentidas sus contribuciones y prestaciones, especialmente respecto a las expectativas de la patronal. Sus dinámicas, planificaciones y resultados suelen presuponer la existencia de hogares unipersonales (con libre o muy flexible disponibilidad horaria) o biparentales (con una presunta paridad en la distribución temporal o rotativa de roles de cuidados en el ámbito doméstico de la pareja o personas adultas convivientes), circunstancia inexistente en la monomarentalidad.

Por estas razones -entre muchas otras; ver detalle en Almeda Samaranch y Di Nella, 2011—, las monomarentalidades suelen experimentar mayor estrés laboral, exceso de cansancio, sobrecarga familiar, falta de tiempo para el autocuidado, dificultades para conciliar el sueño, y sobretodo, obturación casi total para contar con el apoyo comunitario de la red social o de la familia extensa - recordemos; con anterioridad al confinamiento las redes comunitarias eran la principal malla de contención de la gran mayoría de estas familias (Almeda, Camps y Di Nella, 2016)—.

Otro punto de partida generalmente erróneo es dar por sentado que con hijas e hijos adolescentes tal dificultad desaparece. 
Se presupone que ellos/as podrían ayudar y/o asumir algunas o todas las tareas domésticas pero, por el contrario, durante el confinamiento este período vital suele acentuar los conflictos familiares y personales. Por ejemplo, la restricción relacional con grupo de pares o la insatisfacción de otras necesidades propias de las y los adolescentes, quedan supeditadas o subordinadas a las posibilidades del hábitat, la infraestructura de la vivienda y los medios informáticos-comunicaciones disponibles.

Como nos enseñan los feminismos interseccionales, si vamos añadiendo variables sociológicas a la modalidad de convivencia familiar monomarental, tales como la clase social, la pertenencia a una minoría étnica o población originaria, el hecho de ser migrante, tener capacidades especiales o hijos/ hijas con ellas, entre otras variables; las realidades vividas por la inmovilidad humana residencial agudizan notablemente su vulnerabilidad y aumentan las desigualdades, las pobrezas y sus exclusiones.

\section{VII.3. Personas pertenecientes a Pueblos originarios y sectores periurbanos}

Las medidas oficiales dirigidas desde el paradigma del igualitarismo formal $\mathrm{u}$ homogeneidad poblacional se topan con la realidad innegable de la diversidad de pueblos y comunidades indígenas. Estas medidas los invisibilizan y violentan, vulnerando sus derechos y afectando sus estrategias de supervivencia y formas de vida. Tampoco respetan las propias formas de organización política y social de estos pueblos y comunidades, que lejos están de querer reproducir la transmisión del coronavirus. Pero principalmente, se ha vulnerado su derecho humano a la autodeterminación, violentando y restringiendo aún más sus propias formas, sus propios modos de responder desde ese proceso de comunitarización de su vida. Así, por ejemplo, la pregunta de cómo responder comunitariamente para evitar la transmisión del virus, encuentra respuestas radicalmente distintas para los pueblos originarios respecto de aquellas personas 
que están en lugares urbanizados (Di Nella, 2020). Tengamos en cuenta también que las grandes concentraciones poblacionales que tienen los sectores urbanos distan mucho de las realidades de los territorios comunitarios o incluso de muchos barrios populares.

La nuclearización de la familia no es la misma en los países europeos que, por ejemplo, en los sectores populares de las sociedades de Abia Yala-Amerindia. Esto es algo a tener en cuenta para construir medidas menos eurocéntricas y androcéntricas. Los sectores populares tienen modalidades de convivencia y reproducción de la vida y de contención social que no se corresponden con los modelos o tipos idealizados. Por ende, los primeros sectores afectados por las medidas de confinamiento van a seguir siendo aquellas personas que dependen más de estrategias comunitarias de supervivencia y bienestar. Por lo tanto, quienes tienen tendencias a la comunitarización de sus vínculos se verán mucho más afectados/as que quienes sostienen estrategias de mercantilización; en consecuencia, se deben asumir otras respuestas. (Di Nella, 2017).

Por otra parte, es imprescindible asumir que según estas cosmovisiones, cuando se enferma una persona no se enferma el cuerpo sino un sujeto en su integralidad. Este sistema, sin embargo, lo que hace es dejarlo absolutamente solo para que luche contra esa infección viral desde su propia y exclusiva capacidad, hábitat, capital material y resistencia. Sin ningún tipo de contacto con algún familiar o vínculo social significante, ello supone abrir una diferencia abismal entre las personas, según sus posibilidades individuales de superar una enfermedad en condiciones de aislamiento total.

Si bien es cierto que el aislamiento físico resulta necesario para reducir y prevenir las posibilidades de propagación y transmisión del virus, lo que no puede hacerse es soslayar el muy alto costo que tiene el aislamiento para las personas enfermas, especialmente para aquellas que por razones culturales, sociales o económicas, dependen más de sus redes sociovinculares 
y comunitarias. La eficacia del sistema sanitario público no sólo depende de generar más camas y tener más personal, sino también de que las personas no se sientan totalmente aisladas y abandonadas en su forma de transitar la enfermedad.

Lo que estamos planteando es que la inmovilización humana en unidades residenciales de nuclearidad familiar para los colectivos mas vulnerabilizados, caracterizados por el mayor desarrollo de estrategias de supervivencia y dinámicas sociovinculares de base comunitaria no nucleares, conlleva un agravamiento absoluto y relativo de sus condiciones de vida respecto de otros sectores sociales. Esta circunstancia -especialmente reflejada en la realidad de villas y barriadas de las zonas metropolitanas de las grandes ciudades, también merece ser denunciada en su clasismo, etnocentrismo, androcentrismo, adultocentrismo y racismo excluyente, explícito o subyacente.

\section{VII.4. Población migrante y desplazada}

En un modelo que básicamente reduce la posibilidad de movilidad territorial la población migrante se encuentra especialmente afectada, porque va a quedar confinada en territorios en donde no tienen redes socio vinculares amplias.

El cierre de fronteras ha sido una de las primeras medidas adoptadas por los Estados a nivel mundial. Esta medida implica necesariamente un aumento más que significativo de personas en situación de migración forzosa internacional y dentro de cada uno de los países. La precarización laboral, las imposibilidades de acceder a derechos básicos como la educación, la salud o la seguridad social sin DNI, las situaciones de vulnerabilidad de las mujeres frente a las violencias machistas y a la explotación sexual, entre otras; configuran un proceso de deshumanización de las personas migrantes (Butler, 2009).

Por otro lado, el actual gobierno nacional dispuso un Ingreso Familiar de Emergencia (IFE) para trabajadores informales y monotributistas de las primeras categorías. Esta medida, al igual que la AUH, requiere de la "residencia legal" de al menos dos 
años en el país y de DNI. Ahora bien, la ausencia de políticas públicas de regularización migratoria del anterior gobierno nacional no ha hecho más que elevar a cifras exorbitantes el número de personas sin acceso a los trámites de radicación - y por ende a la obtención de DNI-. En consecuencia, gran parte de la población migrante queda excluida de acceder a dichas prestaciones.

Varias autoras y autores (entre otras, Gil Araujo y Rosas, 2020, con quienes coincidimos) proponen que la categoría de "habitante" de un territorio amplía de manera significativa la perspectiva de derechos frente a los estatus jurídicos de "residente" o "ciudadano" utilizados hasta el momento. Esta categoría elimina las distinciones para el acceso a derechos básicos y está reconocida en la Constitución Nacional, cuando establece que el Estado se compromete a "... asegurar los beneficios de la libertad...para todos los hombres del mundo que quieran habitar en el suelo argentino..." (Preámbulo) y que "...Todos los habitantes de la Nación gozan de los siguientes derechos ..." (Artículo 14 y cc.). Se trata de una reivindicación necesaria, no solo en un contexto de emergencia sanitaria vinculada al reconocimiento de la personalidad humana como sujeto de derechos. Las personas migrantes viven situaciones de profunda precariedad material y simbólica, donde más de una vez el acceso a derechos parecería ser un privilegio. Por ello, insistimos, la figura de "habitante" constituye una herramienta legal y discursiva más que necesaria para garantizar sus derechos humanos.

\section{VII.5. Trabajadores/as mercantiles remunerados/as}

Las y los trabajadores de los denominados servicios esenciales son aquellos/as que están destinados/as a dar respuesta directa a la atención de personas; por ejemplo, los/as agentes sanitarios. Pero podríamos pensar también en aquellas personas que han tenido que interactuar en un espacio público restringido así dispuesto en tiempos de pandemia, como por ejemplo, los recolectores de residuos o el personal de seguridad. 
Estas personas no contaron con equipamiento adecuado, oportuno y suficiente, ni mucho menos con un dispositivo de acompañamiento apropiado para la psico-profilaxis sociolaboral y el abordaje de su salud mental.

Las personas trabajadoras del sistema de reparto domiciliario tampoco fueron específicamente previstas; no sólo se las explota, como ya se lo hacía habitualmente con pseudos contrataciones de personal autónomo, sino que hoy esas condiciones las/os dejan totalmente a la intemperie. Incluso el Estado, con la tecnología disponible - por ejemplo, aplicaciones para la geolocalización- podría haber previsto la organización de un dispositivo para facilitar la gratuidad de los envíos a domicilio de toda la sociedad. Esto hubiese reducido, también, la afectación de toda la dinámica mercantil y las condiciones laborales y familiares de las personas que necesitan trasladarse de sus domicilios.

En el caso del personal de seguridad, se construyó un imaginario de intervención puramente represivo, muy lejos de los modelos de una policía comunitaria, sin ningún tipo de capacitación o entrenamiento para la aproximación empática de los sujetos ni para acompañarlos en su comprensión de la necesidad de confinamiento. Estos mismos agentes han quedado más que expuestos y se han transformado en posibles agentes de transmisión y contagio; desarrollando sus actividades y los operativos sin los recursos ni los insumos necesarios para hacer una real prevención.

Por otro lado, se han propuesto múltiples formas de teletrabajo. Es cierto que ya había con anterioridad a la pandemia, una tendencia creciente al trabajo individualizado y domiciliario. En realidad, es parte de un proceso más amplio en el que —en una economía de servicios- los aspectos presenciales han perdido parte de su necesariedad. En efecto, la tendencia al teletrabajo era previa a la COVID-19, especialmente en ámbitos de mayor vulnerabilidad laboral y capacidad patronal para la mayor explotación. Una vez más, con la pandemia lo que ocurre es que 
los procesos en marcha se han agudizado, trasvasando desde los sectores más precarizados al conjunto de la población.

Sin embargo, no todos los sacrificios a los que se ha incoado a la población eran inevitables. Se ha forzado a realizar el trabajo con insumos familiares, naturalizado el uso de recursos personales como el internet y las propias computadoras y esquemas de organización. A ello se le suma la virtualización del proceso de escolarización de personas menores de edad, que implica la exacerbación de la transferencia de las tareas de cuidado y apoyo — principalmente en las mujeres- Cuando se está confinado en el hogar también se reproduce la superposición y la multiplicidad de tareas, de tal forma que el teletrabajo viene a acentuar aun mas las dificultades para dar cobijo al derecho a la desconexión laboral mercantil. Si bien el carácter tuitivo del derecho laboral ofrece cierta protección al respecto, estas condiciones laborales no están explícitamente legisladas, ni sometidas a convenios colectivos de trabajo o paritarias que la contemplen (Távara, 2020). Ello, además de prestarse a diversos abusos, machaca en las desigualdades ya existentes de feminización de los cuidados de la vida humana.

En consecuencia, nuevamente surge la pregunta: ¿Cómo asumir colectivamente la distribución de responsabilidades laborales y qué sacrificios o esfuerzos por parte de toda la población o de algunos sectores resultan necesarios para que eso no recaiga en los sectores más vulnerabilizados?

Respecto a las personas que trabajan en el pequeño comercio urbano de proximidad también caben hacer algunas reflexiones. La concentración oligopólica que caracteriza nuestras economías presenta una gran carterización de las cadenas de producción y comercialización de insumos básicos para la vida cotidiana de las personas inmovilizadas residencialmente. Una política de control de precios no puede sino dirigirse de forma absolutamente prioritaria a estos sectores mercantiles $\mathrm{y}$ sus grandes superficies de ventas. Sin embargo, fueron sistemáticamente autorizadas por el Estado a funcionar sin mayores 
limitaciones, lo que conllevó a una competencia despiadada por los márgenes de ganancia. Esta situación dejó en condiciones realmente adversas a todo el mercado minorista.

Así, el mercado minorista quedó contra las cuerdas. Su única estrategia de comercialización viable ha sido buscar su subsistencia en la oportunidad comercial, a veces vinculada a la franja horaria de atención al público, a veces a la relación de vecindad o proximidad, y otras en calidad de prestamista fiduciario de última instancia de personas de la economía informal sin más aval que la palabra empeñada. En cualquier caso, trabajan con una escala de comercialización muy baja en términos cuantitativos, que obliga a procurar un margen de ganancia por producto en base a un mayor precio que el de las grandes superficies. Efectivamente, puede detectarse una suba de precios en mercados minoristas, sea por el menor circulante monetario y/o por la caída de las ventas. La consecuencia será el aumento de la tasa de ganancia por producto vendido, aunque con una reducción en el número de ventas en comparación con su situación anterior a la inmovilización human residencial ordenada por decreto.

No obstante, las/os pequeñas/os comerciantes han sido presentados/as - torpemente-, como personas simplemente avaras que tienen el mismo afán de rentabilidad que cualquiera de estos corsarios de las grandes superficies. No parecen entender el impacto de las dinámicas de hiper concentración de las ventas en las grandes superficies y supermercados durante el confinamiento residencial. Esta generalización debe ser revisada para evitar la estigmatización de pequeños/as comerciantes que, en todo caso, sostienen los intercambios de base comunitaria. Porque, como sabemos, ellos/as no se han ido de sus zonas de residencia por hincarse en fortunas millonarias.

\section{VII.6. Población inmovilizada en instituciones totales}

Finalmente, cabe mencionar a las poblaciones que se encuentran transitando las diversas instituciones totales; poblaciones 
que están básicamente en situaciones de confinamiento, de encierro o de privación de su libertad.

Todas las instituciones totales comparten algunos rasgos comunes, ya sean geriátricos, psiquiátricos, institutos para personas menores de edad o cárceles. Uno de los rasgos que comparten es que esta modalidad de confinamiento no presupone una concentración reducida de personas. Son modelos que implican, por definición, la masificación, sin ninguna relación con las medidas previstas para ordenar la inmovilización residencial. Más aún, se presenta casi siempre con una realidad de sobre-masificación, lo cual implica que, como estrategia de abordaje preventivo epidemiológico, sea un dispositivo más que paradojal.

Otra particularidad es que esa concentración de personas se produce en la interacción permanente con el personal de contacto que constantemente entra y sale de esas instituciones totales. Su situación de riesgo se ve fuertemente exacerbada, además, porque muchas de las personas son inmuno-suprimidas. En esto, las grandes silenciadas y olvidadas, las que nunca se nombran ni se les permite organizarse ni expresarse, son las personas que se encuentran confinadas en los institutos psiquiátricos.

Otro colectivo que esta invisibilizado son las personas convivientes en geriátricos y centros de día o nocturnos. En muchos países ya está claramente desarrollada la institucionalización de la mercantilización de la vida humana. Allí vemos situaciones en las que se han encontrado a más de 20 personas adultas mayores muertas en un geriátrico. Esto, nuevamente, nos genera una tensión como sociedad, donde la perversión del sistema se expresa en la terrible paradoja de que aquellos lugares para cuidar son los verdaderos agentes de muerte, del "dejar morir" o incluso, del "hacer morir".

Finalmente, creemos necesario puntualizar, lo que resulta un verdadero oxímoron infectológico. Las instituciones totales con personas privadas de libertad, que no solo implican una gran concentración de personas conviviendo, sino que la 
concentración de personas es forzosa e impuesta por el propio Estado que los/as obliga a ese tipo de confinamiento. A más de ello, en el caso de las personas privadas de su libertad nos encontramos con una población en su gran mayoría condenada por delitos menores o incluso solo procesados. $\mathrm{Y}$ en caso de existir condenas, en general los hechos están vinculados a delitos contra la propiedad o están íntimamente relacionados al consumo de estupefacientes.

Por otra parte, se trata de una población con una alta tasa de factores de riesgo por enfermedades previas, donde las medidas para evitar su contagio son extremadamente reducidas. El aislamiento territorial de esos espacios de concentración de personas se centra casi exclusivamente en la restricción de las visitas y/o sus interacciones, sin adoptar ningún tipo de medida efectiva con el personal penitenciario que se encuentra en interacción permanente y rotativa con la población encarcelada.

Toda esta realidad en épocas de pandemia también deja entrever una tensión desorbitante en las lógicas jerárquicas de los derechos y deberes en juego: el deber de punición y control, frente el derecho a la vida y la supervivencia. Pareciera que la única medida factible para que estas personas no se instituyan en el descarte poblacional de nuestras sociedades es el confinamiento en unidades convivenciales de pequeñas dimensiones.

De este modo, la principal medida eficaz para reducir los daños que el Estado provoca a la propia población confinada en establecimientos penitenciarios, no puede ser otra que la desmasificación y la consecuente ubicación en lugares de menor concentración de personas. Esa es la única posibilidad real de evitar el verdadero genocidio en acto que implica la actual política penitenciaria en épocas de coronavirus.

En consecuencia, observamos la necesidad de un abordaje alternativo al modelo securitario del control del cumplimiento de la inmovilización humana residencial en sus diversas fases, incluso para la eficacia del propio modelo previsto. 
En este punto, podemos remitirnos al concepto acuñado por el jurista Raúl Zaffaroni, para referirse a las realidades del sistema carcelario mucho antes de la pandemia: el "genocidio por goteo" (Zaffaroni, 2015), es decir, la eliminación sistemática o generalizada de un grupo humano. El grupo humano víctima tendrá algo en común ya sea la etnia, la nacionalidad o el estar preso; lo sistemático significa que existe una estructura que permite o promueve la muerte y lo generalizado quiere decir que las muertes son múltiples. Como sabemos y es voz populi, las cárceles y otras instituciones totales como las que hemos mencionado son "depósitos" de personas donde la vida y la muerte están divididas por muy finos hilos. Solo queda saber si en contextos de pandemia este genocidio, será por goteo o a chorros.

\section{Regulación de la movilidad y circulación desconcentrada de personas}

Ya sabíamos que las pulgas sueñan con comprarse un perro. Ahora nos consta que los/as infectólogos/as del mundo, al servicio de los Estados y sus decisores gubernamentales, sueñan con un confinamiento inmovilizador de la humanidad. Pero... ¿Era previsible una pandemia? Sí, lo era e incluso ya venía siendo anunciado por la OMS y por diversas personalidades y organizaciones sociales y científicas (Ramonet, 2020, PNUMA, 2016). ¿Era previsible la necesidad de pruebas de laboratorio o test masivos? Sí. ¿Era posible la realización de test masivos? Sí, claro. Y ante la detección temprana de potencial transmisión comunitaria del coronavirus SARS-Cov-19, ¿Es posible la cobertura total de test a personas susceptibles de contagio? Sí. Y si no hay o no se dispone de dichos test, ¿Se agotaron todas las vías posibles de conseguir/producir el test? Nos preguntamos incluso, ¿Se podría simplemente ordenar que quien tuviese síntomas o sea un paciente asintomático con indicadores de riesgo adoptase voluntariamente el autoconfinamiento? Sí. Entonces, solo en el caso de no confiar en la autogestión social cabría 
como única medida la inmovilización preventiva y obligatoria de todo el mundo. Eso sí, lo que siempre es posible si hay test para todos/as, es hacer pruebas de laboratorios masivos y confinamientos solo a las personas contagiadas, de manera mucho más fácil y económica que a toda la población.

Entonces, la medida de confinamiento para la inmovilización masiva se explica sola. Surge como consecuencia de la ausencia o falla de política pública sanitaria respecto de la disponibilidad pruebas de laboratorio para una selección de la población. Y como resultado, también, de la falta de una política pública de salud mental comunitaria, que garantice el acompañamiento psicosocial, comunitario y económico necesario para evitar la concentración de personas, en condiciones de distanciamiento físico, higiene personal y desinfección espacial. Ante estas faltas no hay otra manera de actuar que no sea, claro, encerrando a todo el mundo en casa y reprimiendo y penando a quien no lo pueda cumplir —o no lo quiera hacer, en ejercicio de derechos no restringidos por ninguna sentencia judicial-.

Otro aspecto se relaciona con la valoración del riesgo y las potenciales consecuencias del fracaso de la misma; es decir, la proporcionalidad de la medida. Se trata de ponderar los efectos de la inmovilización, no con la situación epidemiológica actual, sino con el riesgo y los eventuales daños sociales y personales que puede conllevar esta medida respecto de aquellos que se quieren evitar. Por ejemplo:

- Si se extiende, no hay vacunas, no hay curas y, por tanto, habría consecuencias atroces.

- $\quad$ Si se extiende en un tiempo breve y próximo, el sistema sanitario colapsaría (lo que transforma en determinante, ganar tiempo para hacer el sistema sanitario con mas infraestructura y personal, es decir, se restringen derechos para desarrollar políticas que permitan implementar el derecho a la salud),

- Si se extiende en ciertos espacios, no se podría evitar la transmisión en las aglomeraciones con concentración 
de personas (hogares de barrios populares o instituciones totales que conlleva una alta tasa de contagio).

Así, la inmovilización no resulta ser la medida más efectiva para abordar la enfermedad de la COVID-19, ni para evitar la circulación o transmisión del virus SARS-Cov-19. Es solo lo más eficiente para obtener el tiempo necesario a los efectos de poder asumir los déficits de la política publica de salud al momento de producirse la previsible pandemia.

Son muchas las medidas a diseñar y los dispositivos a implementar, para graduar algún tipo de contacto que no implique el aislamiento permanente de las personas en espacios físicos diferenciados - y sin que ello conlleve, claro está, la interacción masiva en el espacio público o en espacios físicos cerrados-.

Entre esas medidas están:

- Test masivos para el conjunto de la población.

- Cuarentenas selectivas para grupos de personas enfermas o personas de grupos de riesgo biomédico.

- Reuniones manteniendo distancia física de 1 metro, como por ejemplo en un supermercado.

- Infraestructura para interacciones físicas antipandémicas, como por ejemplo en una farmacia.

- Insumos y tecnologías para higiene personal y desinfección física espacial (logística de horarios, antiaglomeraciones, reducción de densidad poblacional, desinfección, vestimentas y objetos especiales, etc.).

Es evidente también que en los pueblos pequeños sin transmisión comunitaria del virus, es totalmente viable la adopción de medidas de inmovilización comunitaria no residencial (permitiendo desplazamientos dentro de un pueblo externamente aislado). En lugares con alta densidad poblacional la medida tiene una mayor complejidad pero, aun así —si están puestos los objetivos en evitar la concentración de personas restringiendo y afectando lo menos posible los derechos- es viable.

Otra propuesta es el denominado "Pasaporte sanitario", consistente en una serie de controles previos - y generalmente 
voluntarios - de las personas para que se "visen" un conjunto de indicadores de ausencia de carga viral en el organismo, con un eventual seguimiento por geolocalización o red móvil internacional (Ramonet, 2020). Esto permitiría la libre circulación de las personas sin afectación de sus derechos.

Desde otra perspectiva, también cabe destacar que el ocio y esparcimiento en el espacio público no provoca, necesariamente, concentración de personas, si el mismo es regulado (distanciamiento, densidad poblacional movilizada presunta, etc.). La concentración de personas es provocada por el ocio desregulado y la producción masiva de mercancías para la renta del capital (porque la producción para el autoconsumo, tampoco) ¿Que tanto pierde -o cuanto menos gana- el gran capital? Se podrían privar o restringir menos derechos - por ejemplo, a la convivencia comunitaria, a la visita y relación familiar o por círculos relacionales con asistencia técnica de proximidad-, pero necesariamente la gradualidad debería discriminar lo que más concentración de personas genera: la producción mercantil de bienes.

En el ámbito de las relaciones personales podrían generarse con agentes de salud comunitaria, modalidades de aproximación y interacción familiar segura y asistida. Por ejemplo, de contacto entre integrantes de familias extensas que, sin entrar en la interacción física, puedan reducir el impacto producido por el aislamiento vincular. Se trataría de permitir el contacto directo - con los controles necesarios e incluso a una distancia prudencial- durante determinado tiempo, en lugares acondicionados para ello.

Otra medida fundamental para prevenir la enfermedad de la COVID-19 es la organización del dispositivo sanitario para la atención médica fuera del modelo médico hegemónico tradicional de la enfermedad. Para ello, es fundamental, asumir las perspectivas feministas interseccionales que nos señalan la confluencia de los regímenes de bienestar y las políticas públicas de salud en la asunción de tiempos y tareas de cuidados desde los sectores comunitarios, privados y estatales. En efecto, no 
corresponde asimilar las políticas públicas a las prestaciones estatales. La propia comunidad ha tenido que asumir autogestionadamente gran parte de dichos cuidados, especialmente respecto a la salud mental de la población no hospitalizada en la sección de agudos.

Así, el dispositivo sanitario debe ser reconocido y diferenciado en por lo menos 3 instancias de abordaje de la COVID-19. En primer lugar, encontramos la situación de aquellas personas asintomáticas o eventualmente con síntomas menores. Su abordaje requiere una intervención estatal reducida a la regulación de la medicalización y el seguimiento de un confinamiento domiciliario. El sistema sanitario público absorbe, descansa y descarga - casi por completo- en los propios recursos comunitarios residenciales, es decir, en las unidades de convivencia familiar —en general y mayoritariamente, en las mujeres que lo integran-. En consecuencia, la gestión de la prevención y los insumos necesarios para evitar el contagio de quienes van a estar recluidos en una casa, implica una delegación de la logística y los cuidados sanitarios respectivos, al sector más femenizado de la comunidad.

En segundo lugar, encontramos la situación de aquellas personas con síntomas graves, cuyo abordaje requiere una internación y asistencia hospitalaria. Eso implica una disponibilidad de camas, acompañamientos e infraestructuras que no disponen los endebles sistemas sanitarios estatales y privados. En consecuencia, el sistema sanitario público se nutrirá no solo de los recursos de salud estatales (una parte de la infraestructura de internación hospitalaria y de los centros de atención primaria) y privados (camas en sanatorios, clínicas y hospitales privados). Incorporará también los recursos de salud comunitarios residenciales (hogares con capacidad de absorver total o parcialmente los cuidados intensivos) y no residenciales (gimnasios, clubes deportivos, y otras infraestructuras comunitarias en condiciones de servir como improvisados campamentos sanitarios) para permitir que una gran cantidad de personas reciba los cuidados intermedios y los acompañamientos sanitarios correspondientes. 
En tercer lugar, encontramos la situación de aquellas personas con síntomas agudos, cuyo abordaje requiere una internación y asistencia hospitalaria en zonas de terapia intensiva o con asistencia respiratoria. En estos casos, se ha pensado el abordaje del tratamiento de la enfermedad desde el dispositivo de asistencia médica hospitalaria. En efecto, el sistema sanitario público se ha diseñado casi exclusivamente desde los recursos estatales hospitalarios, básicamente en modalidades de mayor aislamiento posible de las personas enfermas.

Como puede verse, los dispositivos de salud pública han contado predominantemente con recursos estatales, privados y comunitarios destinados al abordaje de personas portadoras del virus SARS-Cov-19. Pero poco y nada han instrumentado para el abordaje de la salud mental de toda la población y el acompañamiento de los cuidados de la vida humana, tanto en las tres instancias mencionadas como en personas no contagiadas, especialmente en el enorme espacio intermedio que hay entre la autogestión de los efectos de la inmovilización residencial en unidades de convivencia familiar y la atención de personas con cuidados en la internación intrahospitalaria.

Por último, cabe decir que muchas de estas medidas han sido implementadas progresivamente, desde el momento en que este artículo comenzó a pensarse. Es posible entonces que algunas afirmaciones y discusiones puedan ir quedando saldadas. Pero lo que no se ha modificado, es la lógica de excepción y la consecuente restricción de derechos que estas medidas aún suponen y que siguen afectando de modo muy diferencial a sectores totalmente excluidos de las lógicas de implementación de las políticas públicas. Por ello, insistimos, la premisa inicial continúa siendo el confinamiento y la restricción de derechos.

\section{El modelo iushumanista, comunitarista democrático participativo, como alternativa de control del cumplimiento de la movilidad desconcentrada de personas}

Resulta imperioso reaccionar ante la propuesta estatal de regulación y control que promueve conductas asertivas 
absolutamente funcionales a la adhesión acrítica de órdenes estatales. Como sociedad no podemos limitarnos a reproducir las máximas positivistas "dura lex, sed lex" (dura es la ley, pero es la ley), perspectiva en donde la ley hay que cumplirla porque es la ley.

En realidad, la capacidad de obediencia que tiene la sociedad es apabullante. Cualquier sistema social funciona a partir de la obediencia, y no solo en lo regímenes totalitarios; la democracia misma se basa en la obediencia voluntaria a la decisión colectiva soberana, asumiéndolas con responsabilidad y lealtad. La distinción la encontramos en la concepción del poder. Podemos referirnos a la orden estatal como disciplina de obediencia a los pueblos que lo integran, construida en base a consensos sociales compartidos por los sectores más excluidos de la misma. O podemos referirnos al poder estatal como expresión de su capacidad de forzar la obediencia a decisiones sin consenso democrático en beneficio de los sectores dominantes. La diferencia es relevante; de ello devendrá el ejercicio del poder estatal como un mandato de obediencia popular, o como un acto de mera dominación social (Dussel, 2016). Incluso, cualquier convivencia humana basada en normas compartidas implica un cierto grado de obediencia voluntaria en las formas toleradas de desobediencia. En cierta jerga se la denomina tener "códigos", en otras son imperativos morales, pero lo cierto es que rebelarse puede ser también, en ciertos casos, una obligación.

En este sentido, más de una vez, gran parte de la población debió asumir la lucha contra su propia "zona de sacrificio" ante leyes o decisiones gubernamentales que resultaban profundamente injustas. Entonces, se apeló al legítimo recurso de resistir a la opresión, como derecho a resistir al derecho positivo vigente. Para Rita Segato, la ley es

“...un campo de lucha donde, sin duda, el juego de las fuerzas en conflicto y el control de la fuerza bélica es decisivo, en última instancia. Su legitimidad y el capital simbólico que representa para la clase que la controla y administra depende de que contemple desde su estrado 
un paisaje diverso, en cuyo contexto preserva la capacidad de mediación..." (2004, p. 6).

El derecho puede quedar absolutamente viciado, licuado en esta máxima de cumplir la ley por su mera fuerza normativa, sin ninguna canalización institucional efectiva para poner en valor los propios derechos humanos como constructo axiológicamente superior de los estados democráticos de derechos. En esas circunstancias, resulta una opción necesaria la resistencia a ese marco normativo. Se les propone a extensos colectivos vulnerabilizados de la sociedad su resignada asunción de prácticas sanitarias. Para ellos, tal mansa asunción no puede resultar sino en su automutilación extirpadora de la sociedad. Por esta razón, la respuesta social que estos colectivos dispongan ante la pandemia debe pasar por la gestión y organización comunitaria de prácticas que no les resulten suicidas, se adapten o no a ciertos actos administrativos ministeriales.

Otro aspecto del análisis tiene que ver no ya con el mero condicionamiento por amedrentamiento o represión para que se cumplan las normas que establecen la inmovilización residencial, sino con las causas de los "incumplimientos". Observando esas causas, vamos a encontrar condiciones de factibilidad material absolutamente desiguales. Un ejemplo son las personas cuyas estrategias de supervivencia se nutren de la explotación económica por la venta mercantil ilegal de su fuerza de trabajo (changarines, trabajadoras de casas particulares, empleados tercerizados como falsos autónomos, entre otras). Ante el confinamiento domiciliario, éstos se encuentran con la pérdida casi total de sus ingresos dinerarios y la paralización y/o ruptura total de las redes socio-comunitarias de solidaridad e intercambio en especie de bienes y servicios indispensables para su subsistencia. Claramente, su remedio no será una prestación económica excepcional de $\$ 10.000$ en los grupos familiares con personas menores de edad o bonos de 3000 pesos para jubilados/as; el abordaje requerido es mucho más complejo.

Por otro lado, en condiciones tan adversas como las de estos colectivos, se hace inviable sostener el confinamiento 
exigido con la Inmovilización Humana Residencial Masiva, sin poner a disposición los dispositivos de contención psicosocial y vincular requeridos para cumplir con esta medida.

En efecto, resulta necesario reforzar esta construcción vincular y comunitaria en toda su complejidad e integralidad. No se trata de salir a tomar el aire y dar una vuelta, como quien satisface una necesidad fisiológica propia o de los perros que se paseen. Se trata de una respuesta psicosocial de fortalecimiento comunitario y re-construcción de la malla vincular de contención de las personas, procurando que el aislamiento y distanciamiento social no se transformen en aislamiento vincular. Ante cada pandemia debe asumirse que las personas necesitamos vincularnos incluso físicamente, tejiendo estas redes de construcción y convivencia comunitaria.

Ello requiere de dispositivos de intervención que aborden las necesidades sentidas de la sociedad durante su confinamiento. El personal de salud mental comunitaria debe coadyuvar a un trabajo colectivo con todas las personas damnificadas por las medidas preventivas adoptadas en virtud de la situación crítica -y no necesariamente, o solo, sobre las personas con patologías psíquicas preexistentes-.

Estos modelos son, respecto a la Inmovilización Humana Residencial Masiva, mucho más efectivos; por lo menos, en términos de respeto de los derechos humanos, del derecho a la vida, a la salud, del derecho de reunión, de los derechos de relacionamiento social y, especialmente, para ejercerlos en una democracia participativa que inocula como paradigma su menor restricción posible.

En consecuencia, cabe partir de una intervención direccionada a re-vincular, para escuchar activamente, interactuar con estas personas confinadas, y enfrentar las limitaciones y violencias de los modelos de control que no buscan las causas generadoras de las pandemias y sus enfermedades. Construir, en definitiva, estrategias de sostenimiento de los confinamientos en las situaciones de desastres, con capacidad de intervenir 
social y comunitariamente en la generación de dinámicas de encuentro y contención comunitaria (Di Nella, Y. y Di Nella, D., 2020).

En suma, como afirmó ya en los años 50 del siglo pasado Pichón Riviere, “...En tiempos de incertidumbre y desesperanza, es imprescindible gestar proyectos colectivos desde donde planificar la esperanza junto a otros...”.

\section{Reflexiones Finales}

Ya no es novedad que el capitalismo salvaje y sus diversas formas de crueldad, no resultan sustentables para la vida humana ni para los recursos naturales que nos rodean. Tampoco lo es que esta pandemia nos encuentra en sociedades absolutamente desiguales. En muchos países se anuncia como respuesta a ello en la post-pandemia COVID-19, la inyección de grandes sumas de dinero público y un rescate universal. Aspiran a que con eso se garantice un orden -o por lo menos cierto orden o estabilidad mundial-, apto para sustraer del devenir las acciones de protesta y la reconducción que puedan incoar los movimientos sociales. El tardocolonialismo financiero pretenderá tranquilizar así a las masas, en base de medidas que no afectarán la distribución del poder y la riqueza. Es un retorno -al menos, metafórico- al impulso del Estado de Bienestar, que justamente llegó después de una crisis.

Para su implementación, se está diseñando un centralismo estatal con capacidad de imponer reglas comunes para toda la población. Lo primero que aparece, es que la principal de estas medidas ha sido el denominado aislamiento preventivo social y obligatorio. Según hemos justificado aquí, esta medida es en realidad una inmovilización humana residencial masiva por confinamiento forzado en unidades de convivencia familiar nuclearizada con privación y/o restricción generalizada de derechos, a los fines de reducir la concentración de personas. Lo segundo a observar, es la exacerbación de los rasgos tradicionales del Estado gendarme para procurar su cumplimiento: cierre 
de fronteras; restricción generalizada de derechos; vaciamiento del espacio público; condicionamiento de las estrategias de organización comunitaria; homogeneización de la diversidad de determinantes sociales de riesgos de contagio a través de la sobre ponderación de las personas de riesgo por determinantes biopolíticos. Así, las personas de edad avanzada, las mujeres en situaciones de embarazo o las/los trabajadores sanitarios, serán los únicos destinatarios de la protección, asimilándolos al concepto de población de riesgo. El resto, debería estar totalmente integrado a sus reglas estandarizadas, centradas en la medida de la inmovilización masiva referenciada mediáticamente por el excluyente lema "\#Quedate en casa”. Pero la realidad es tozuda; los efectos de las medidas estatales son claramente diversos en cada colectivo o comunidad en particular.

En escenarios como el actual, los derechos humanos no pueden ser privilegios de unos pocos. El reconocimiento como sujeto de derechos, inherente a la condición humana, es una obligación internacional asumida por los Estados en múltiples Tratados internacionales. La condición de "habitante" del mundo debería bastar para garantizar el acceso sociológicamente igualitario a esos derechos, porque recordemos: ninguna persona puede ser ilegal.

Desde este enfoque de derechos y de forma más propositiva, la congruencia y proporcionalidad reclamada a las medidas adecuadas para la prevención de la transmisión comunitaria del virus SARS-Cov-19 la encontramos en las adoptadas por diversos países que se han encargado de reducir o eliminar - con muchísimo éxito- las negativas consecuencias descriptas en este trabajo. La principal de las medidas ha sido la selectividad de las personas que quedan obligadas al confinamiento, evitando esa anticipación genérica que conlleva la inmovilización humana residencial masiva. Para ello, como hemos comentado, dispusieron de pruebas de laboratorio por test de coronavirus con un dispositivo muy ampliado pero destinado exclusivamente a aquellas personas que portan la enfermedad y de todas las personas de su entorno. A estas personas se las somete a 
medidas muy estrictas y obligatorias de confinamiento, pero no al resto de la sociedad que, aun con las precauciones sanitarias correspondientes, se mantiene en pleno ejercicio de sus derechos. El control sobre las personas portadoras de la carga viral se efectúa, además, durante un tiempo limitado y articulado entre el de cuarentena y el del tratamiento de la enfermedad.

Por supuesto, hacer ese seguimiento cuando hay 100.000 personas contagiadas es radicalmente diferente a cuando hay 1000 personas. Desarrollar ese control con premura es lo que garantiza la capacidad de anticiparse a la circulación comunitaria del virus y a la transmisión de la enfermedad para poder adoptar medidas de desconcentración de personas que no conlleven la inmovilización humana residencial masiva de toda la población. Subsidiariamente, y antes que la inmovilización masiva, cabe recurrir a medidas de control por pruebas de hisopados o test para toda la población, es decir, también para los casos asintomáticos con susceptibilidad de riesgo de contagio.

Este tipo de control del contagio permite que la persona asuma su responsabilidad. A su vez, da la posibilidad de saber si se porta el virus o no, incluso siendo asintomático. Consecuentemente, las medidas se efectúan con mayor tranquilidad y predisposición que en el caso del confinamiento por mera anticipación. Asimismo, la actividad social y comunitaria se vería mucho menos afectada, al igual que el régimen de salud pública, previniendo su saturación.

Recordemos también que para algunas personas y grupos sociales es muy fácil cumplir la inmovilización residencial; y para otras es prácticamente imposible o inevitable. Es necesario diferenciar, matizar y adecuar a cada habitante y a los diversos grupos sociales las políticas públicas efectivas para que no deriven en un igualitarismo puramente formal. Ello incluye la construcción de indicadores de éxito de las políticas públicas que - por su generalización o referencia a la media del conjunto de la sociedad- no se tornen absolutamente arbitrarias para la gran mayoría de sus destinatarias. 
En esa dirección, los Estados deben evitar el mero despliegue de agentes de ley y orden para el control punitivo-represivo de la población. Por el contrario, caben políticas públicas integrales que garanticen también y principalmente agentes de salud comunitaria para el acompañamiento y primeros auxilios psicológicos de toda la población. Por un lado, claro está, incluyendo a la que quedará en confinamiento físico diferenciado. $\mathrm{Y}$ por otro lado, con dispositivos de salud socio-comunitarios para el resto de la población, de tal forma que puedan cumplir en las mejores condiciones posibles el distanciamiento físico, la higiene personal y la desinfección de su espacio circundante.

El modelo de abordaje de la pandemia que se ha propuesto en este texto, de intervención selectiva y contención comunitaria de la salud mental de toda la población, no incita a la ausencia de medidas socio-sanitarias al solo efecto de facilitar la producción mercantil; no adhiere a la temeraria abstención o dejación de cometidos estatales indelegables en materia de salud pública; no pretende exarcerbar las libertades individuales de los privilegiados de siempre en detrimento de los derechos de los colectivos mas vulnerabilizados a su supervivencia. En cambio, es un modelo que no afecta la integralidad de los derechos humanos, ni confunde la prevención de transmisión viral con una difusa anticipación de mediatas o remotas relaciones de causalidad entre las acciones humanas restringidas y el riesgo real a evitar. Las medidas llevadas a cabo en las primeras semanas de confinamiento residencial familiar, han permitido que el régimen de salud pública se recueste casi exclusivamente sobre los recursos socio-comunitarios de cuidados en el ámbito doméstico, generalmente feminizados. También, han sido aptas para dotar de tiempo a los sectores estatales para el montaje de estructuras sanitarias de emergencia biomédica, que no obstante las retrataron en su precariedad.

Aunque sabemos que muchas de las consideraciones y propuestas al momento de escribir este artículo han comenzado a ser implementadas, seguimos insistiendo que no estamos ante un estado de excepción y que las consecuencias de las medidas 
sobre los colectivos más vulnerabilizados pueden ser —en términos socioeconómicos y en cantidad de muertes derivadasaún peores que los del propio virus.

Por eso, no podemos dejar de observar y revisar las consecuencias nocivas de la delegación del poder decisional sobre los asuntos que nos afectan a todos/as en instancias centralizadas y concentradas del ámbito gubernamental. Las personas que deciden en nombre de esos gobiernos siguen siendo personas de carne y hueso que están resolviendo hasta sobre nuestras vidas. Como pueblos, no podemos quedar al designio de la voluntad artesanal del/la buen/a o mal/a gobernante/a de turno. Las consecuencias que padezcan nuestras comunidades ante esta pandemia tampoco deben quedar sometidas a las características personales de quienes, circunstancialmente, nos gobiernan.

La inmovilización humana residencial puede y debe ser sustituida por medidas cogestionadas intersectorialmente, más eficientes y justas. Esas formas de democratización participativa y comunitaria de la gestión y abordaje de las situaciones de desastres, catástrofes y otros incidentes críticos, como la pandemia de la COVID-19, son la única garantía de obediencia de la representación política al poder popular soberano. De otra forma, la representación política se constituye en mera dominación social al servicio de los sectores dominantes del tardocolonialismo financiero.

Resulta imperioso, entonces, apropiarnos del territorio que habitamos, anclándonos en un paisaje que excede lo estrictamente natural. Lejos de las lógicas capitalistas, debe hacerse desde la plena consciencia que nos constituye y sostiene vincularmente con quienes compartimos la vida.

Salvar vidas y asumir el resto de las consecuencias de las pandemias ya desatadas, puede y debe hacerse, democratizando los espacios públicos y comunitarios necesarios para reducir sus daños y erradicar las causas que las generan. Nos gusta pensarlo. Y tenemos el derecho de hacerlo. 


\section{Referencias bibliográficas}

Almeda Samaranch, Elisabet (20/04/2020). Cárceles de mujeres y desigualdad en época de coronavirus. Columna del Col-lectiu de Solidaritat ambos els Països Catalans de Viedma-Patagones. Recuperado el 30/04/2020 de https://www.adalqui.org.ar/ carceles-de-mujeres-y-desigualdad-en-epoca-de-coronavirus/.

Almeda Samaranch, Elisabet; Camps Calvet, Clara; Di Nella, Dino; Ortiz, Rosa (2016): Familias monoparentales, inclusión y comunidad. ARXIUS de Ciències Socials. Vol. 34; pp. 59-78. ISSN: 1137-7038. Valencia: UV.

Almeda Samaranch, Elisabet; Di Nella, Dino (Eds.) (2011). Las familias monoparentales a debate (Cinco volúmenes). Barcelona: Copalqui Editorial.

Andersen, Inger (03/04/2020). Coronavirus: llego para quedarse?. Recuperado el 30/04/2020 de https://www.unenvironment. org/es/noticias-y-reportajes/reportajes/coronavirus-llegopara-quedarse

Aniyar de Castro, Lolita (1999). La participación ciudadana en la prevención del delito. Antecedentes, debates y experiencias. Maracaibo: Universidad de Zulía.

Aranda, Darío (07/05/2020). ¿La pandemia del pensamiento único?: Reflexiones más acá del cientificismo. Recuperado el 13/05/2020 de https://www.lavaca.org/notas/la-pandemiadel-pensamiento-unico-reflexiones-sobre-el-discurso-cie ntifico/?fbclid=IwAR1DB1uOe7A6c5YYn6zzxOnHf0jcXe91taZXEr6mpvrhvQHHjAu4mSh0J

Arredondo, Armando (1992). Aportes de las ciencias sociales para el análisis de la morbi-mortalidad. Revista Mexicana de Educación Médica. México: Educación Médica.

Butler, Judith (2009). Dar cuenta de sí mismo. Violencia, ética y responsabilidad. Buenos Aires: Amorrortu Editores.

Camps, Clara; Di Nella, Dino (2020). Contra hegemonías antirrepresivas. Un estudio de caso de la protesta en Barcelona (2011-2015). Revista Política y Sociedad, 57(1); pp. 146-173. ISSN: 1130-8001. DOI: https://doi.org/10.5209/poso.60271. Madrid: España. 
Castel, Robert (1997). Las metamorfosis de la cuestión social. Una crónica del salariado. Buenos Aires: Paidós.

Di Nella, Dino (2006). Exclusión Social y Grupos Vulnerables. Barcelona: Copalqui Editorial.

Di Nella, Dino (2017). Dinámicas de Género, Familia y Hábitat en mujeres urbanas mapuche. Familias monoparentales, vulnerabilidad social y acceso al suelo, la vivienda y el hábitat urbano en el valle inferior de río Negro. Proyecto de Investigación UNRN-40-C-649. Resolución Rectoral No 332/18. Viedma: Universidad Nacional de Río Negro.

Di Nella, Dino (2018). Derechos Humanos y Desigualdades Sociales. Redea, Revista Derechos en Acción, Vol. No 8; pp. 54-79. ISSN: 2525-1678. La Plata: Universidad Nacional de La Plata.

Di Nella, Dino; Almeda Samaranch, Elisabet y Ortiz, Rosa (2014). Perspectiva no androcéntrica en los estudios sobre familias monoparentales. Reflexiones e implicaciones metodológicas. Athenea Digital. Revista de Pensamiento e Investigación Social, (14) 2; pp. 181-207. Bellaterra: Universidad Autónoma de Barcelona.

Di Nella, Dino; Giordana, Patricia; Loggiacco, Camila; Arribas, Julián; D’Alfonso, Luis; Almeda, Elisabet; Camps, Clara, (2019). Sociología, Derecho y desigualdades sociales. ARXIUS de Ciències Socials, vol. 40; pp. 65-70. ISSN: 1137-7038. Valencia: UV.

Di Nella, Dino; Ibáñez, Victoria (2020). Pueblos, libre determinación y pluralismo jurídico. Aproximación sociojurídica crítica en Puelmapu y el Principat de Catalunya. Revista Clivaje. Estudios y testimonios sobre el conflicto y los cambios sociales; ISSN: 2014-6590. Barcelona: Universidad de Barcelona

Di Nella, Yago, Di Nella, Dino (2020). "Operar es vincular". Movimientos sociales, prácticas profesionales y políticas públicas de salud comunitaria, para el ejercicio del derecho humano a la salud mental de la población. Revista electrónica Cuestion/ Question. Vol. 1, mayo: Incidentes III. Parte I: Prácticas; DOI: https://doi.org/10.24215/16696581e319. La Plata: Universidad Nacional de La Plata.

Di Nella, Yago; Yacachury, Martín (2018). Abordaje Psicosocial en situaciones de desastres, catástrofes e incidentes críticos. Fundación Adalquí. Recuperado el 30/04/2020 de https://operares 
vincular.adalqui.org.ar/wp-content/uploads/2020/03/Di-Nellay-Yacachury-2018-Abordaje-Psicosocial-en-situaciones-de-desastres-catástrofes-e-incidentes-cr \%C3 \%ADticos-2.pdf

Dussel, Enrique (07/12/2016). Decolonialidad del poder. Ruta pedagógica. Recuperado el 30/04/2020 de http://www.comunalizarelpoder.com.ve/sentidos-comunes/decolonialidad-delpoder/modulo-1

Dussel, Enrique (2006). 20 tesis de política. Por Enrique Dussel; pp. 176. México: Siglo XXI: Centro de Cooperación Regional para la Educación de Adultos en America Latina y el Caribe.

Fiore Viani, Gonzalo (24/10/2019). La hora de los Pueblos. Portal Tinta Roja. Recuperado el 07/05/2020 de https://latinta.com. ar/2019/10/la-hora-de-los-pueblos/

Foucault, Michel (1974). La naissance de la médecine sociale. Segunda conferencia del curso de Medicina Social de la Universidad del Estado de Río de Janeiro. Río de Janeiro: Universidad del Estado de Río de Janeiro.

Frenk, Julio (et. al.) (1991). Elements for a theory of transition in health. Revista de Salud Pública de México; Vol. 33 (5), pp. 448-462; ISSN: 0036-3634. México: Instituto Nacional de Salud Pública.

Gil Araujo, Sandra; Rosas, Carolina (30/04/2020). De extranjeros y habitantes en tiempos de pandemia. Sociología en cuarentena. Recuperado el 13/05/2020 de https://sociologiaencuarentena. tumblr.com/post/616821948793716736/de-extranjeros-y-habitantes-en-tiempos-de-pandemia

Guardo Mónica (2018). El abordaje de "Una Salud", más esencial que nunca. Revista Peruana de Medicina Experimental y Salud Pública; 35 (4); pp. 558-60; ISSN: 1726-4642; DOI: https://doi. org/10.17843/rpmesp.2018.354.4144. Lima: Instituto nacional de Salud.

Harrington, Thomas (23/05/2020). L'independentisme hauria d'estar, ideològicament, contra el confinement. Recuperado el 24/05/2020 de https://www.vilaweb.cat/noticies/lindependentisme-hauria-destar-ideologicament-contra-el-confinament/.

Instituto de Salud Socioambiental (InSSA) (23/04/2020). Hoy COVID-19... ¿y mañana?. Recuperado el 07/05/2020 de http:// 
www.biodiversidadla.org/Recomendamos/Hoy-COVID-19y-manana

Lavaca Coop. (06/04/2020). 100. Editorial. Portal La Vaca. Recuperado el 07/05/2020 de https://www.lavaca.org/notas/cien/

Lévinas, Emmanuel (1993). Humanismo del otro hombre. Madrid: Caparrós Editores.

López Garrido, Diego (09/05/2020). FAQS, Debat sobre l'estat d'alarma. Preguntes Freqüents, TV3. Recuperado el 10/05/2020 de https://www.ccma.cat/tv3/alacarta/preguntes-frequents/ preguntes-frequents-lluis-llach-el-catedratic-diego-lopezgarrido-i-el-periodista-salvador-alsius/video/6042203/

Mastrangelo, Matías; Ruiz, Guillermina (29/03/2020). "Cinco formas en las que transformando el ambiente creamos una pandemia". Recuperado el 30/04/2020 de https://www.lavaca.org/notas/ cinco-formas-en-las-que-transformando-el-ambiente-creamosuna-pandemia/

Mbembe, Achille (2003). Necropolitics. Public Culture, Volume 15, Number 1; pp. 11-40. New York: Duke University Press. Recuperado de https://muse.jhu.edu/article/39984.

Müller, Mónica (2010). Pandemia: Los secretos de una relación peligrosa: Humanos, virus y laboratorios. Buenos Aires: Editorial Sudamericana.

Programa de las Naciones Unidas para el Medio Ambiente (PNUMA) (2016). Frontiers 2016: Emerging issues of environmental concern. Recuperado el 07/05/2020 de https://www. unenvironment.org/resources/frontiers-2016-emerging-issuesenvironmental-concern

Queralt, Joan (09/05/2020). FAQS, Debat sobre l'estat d'alarma. Preguntes Freqüents, TV3. Recuperado el 10/05/2020 de https:// www.ccma.cat/tv3/alacarta/preguntes-frequents/preguntesfrequents-lluis-llach-el-catedratic-diego-lopez-garrido-i-elperiodista-salvador-alsius/video/6042203/

Ramonet, Ignacio (29/04/2020). Coronavirus: La pandemia y el sistema-mundo. Recuperado el 30/04/2020 de https://www. pagina12.com.ar/262989-coronavirus-la-pandemia-y-el-sistema-mundo

Santos, Boaventura de Sousa (12/05/2020). Coronavirus: La pandemia, los Estados y el mercado. Recuperado el 13/05/2020 de 
https://www.pagina12.com.ar/265415-coronavirus-la-pandemia-los-estados-y-el-mercado

Segato, Rita (2004). Antropología y Derechos Humanos: alteridad y ética en el movimiento de los Derechos universales. En Cañón, Hugo Omar (org.): Derechos Humanos: sistemas de protección. Buenos Aires: Universidad Nacional de Quilmes / Prometeo.

Sztajnszrajber, Darío (24/04/2020). Pensar la Cuarentena. Universidad Nacional de Hurlingham. Recuperado el 30/04/2020 de https://www.youtube.com/watch?v=NeU8J0nTjE8

Távara, Melissa (25/05/2020). El derecho a la desconexión laboral. LP es el portal jurídico. Recuperado el 25/05/2020 de https:// lpderecho.pe/derecho-desconexion-laboral-regulacion-peru/

Ugarte Pérez, Javier (Comp.) (2005). La administración de la vida. Estudios biopolíticos. Barcelona: Anthropos.

Zaffaroni, Raúl Eugenio (12/05/2020). Nuestro derecho y la postpandemia.La Tecl@ Eñe. Recuperado el 13/05/2020 de https:// lateclaenerevista.com/nuestro-derecho-y-la-postpandemia-pore-raul-zaffaroni/?fbclid=IwAR3cllmwRwz8ciYPqdflrPrs4qrqnH 5vY5PXDTGF5AT7XKB7tjVUWRiAQs4

Zaffaroni, Raúl Eugenio (2015). Violencia letal en América Latina. Cuadernos de Derecho Penal (139; pp. 57-76; ISSN: 2027-1743. https://doi.org/10.22518/20271743.455 